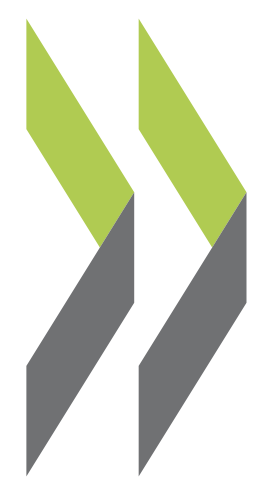

OECD Economics Department Working Papers No. 905 Reaping the Benefits of a Transition to Greener Caroline Klein Growth in Slovakia 
Organisation de Coopération et de Développement Économiques

Organisation for Economic Co-operation and Development

22-Nov-2011

ECONOMICS DEPARTMENT

English - Or. English

REAPING THE BENEFITS OF A TRANSITION TO GREENER GROWTH IN SLOVAKIA

ECONOMIC DEPARTMENT WORKING PAPERS No. 905

by Caroline Klein

All Economic Department Working Papers are available through the OECD internet website at www.oecd.org/eco/workingpapers

JT03311882

Document complet disponible sur OLIS dans son format d'origine

Complete document available on OLIS in its original format 


\section{ABSTRACT/RÉSUMÉ \\ Reaping the benefits of a transition to greener growth in Slovakia}

The transition to a greener economy supported by international environmental commitments and national policies will entail structural changes in consumption patterns and industry structures, resulting in a reallocation of resources in and between countries. Slovakia will need to build an effective framework for green growth to maximise its chances of exploiting cleaner sources of growth and to seize the opportunities to develop new green industries, jobs, and technologies. This requires addressing environmental externalities (for example by extending environmental taxation and removing subsidies) and improving the adaptive capacities of the economy through eco innovation. Reforms to support innovation and R\&D spending, such as making existing R\&D public support more efficient, strengthening the protection of property rights and developing the venture capital market, are needed. Also, administrative entry barriers in the product market should be reduced, competition in energy markets fostered, and the tertiary education system reformed. This paper relates to the 2010 OECD Economic Review of the Slovak Republic (www.oecd.org/eco/surveys/slovakia).

JEL classification: H23 ; O44 ; Q58

Keywords: Green Growth; climate change; innovation; Slovakia

\section{Concrétiser les avantages de la transition vers une croissance plus verte en Slovaquie}

La transition vers une économie plus verte en s'appuyant sur les engagements internationaux en matière d'environnement et les politiques nationales impliquera des évolutions structurelles des modes de consommation et des structures industrielles, processus qui entrainera un redéploiement des ressources dans et entre les pays. La Slovaquie devra mettre en place un cadre efficace pour verdir sa croissance afin de maximiser ses chances d'exploiter des sources de croissance plus propres et de développer des secteurs, des technologies et des emplois nouveaux et respectueux de l'environnement. Elle devra pour cela s'attaquer aux externalités environnementales (en augmentant la fiscalité environnementale et en éliminant des subventions, par exemple) et améliorer les capacités d'adaptation de l'économie via l'éco-innovation. Des réformes sont nécessaires pour soutenir l'innovation et les dépenses de $\mathrm{R} D$, notamment rendre plus efficient l'allégement fiscal pour la $\mathrm{R} \mathrm{D}$, renforcer la protection des droits de propriété intellectuelle et développer le marché du capital-risque. En outre, il conviendrait d'abaisser les barrières administratives à l'entrée sur le marché des produits, de stimuler la concurrence sur les marchés de l'énergie et de réformer l'enseignement supérieur. Ce document se rapporte à l’Étude économique de la République slovaque 2010 (www.oecd.org/eco/etudes/slovaquie).

Classification JEL: H23 ; O44 ; Q58

Mots clés : Croissance verte ; changement climatique ; innovation ; Slovaquie

Copyright ( $)$ OECD, 2011. All rights reserved. Application for permission to reproduce or translate all, or part of, this material should be made to: Head of Publications Service, OECD, 2 rue André-Pascal, 75775 PARIS CEDEX 16, France. 


\section{TABLE OF CONTENTS}

Climate change mitigation and increasing energy efficiency are two major challenges .............................5

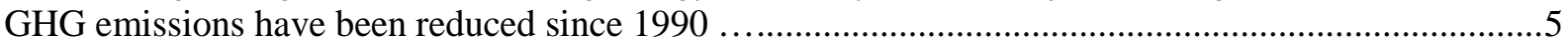

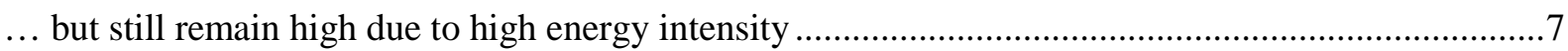

Reducing GHG emissions and energy intensity is highly desirable .................................................

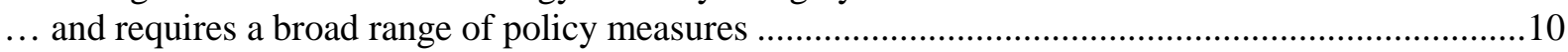

Addressing the challenge of making economic growth more environmentally sustainable ......................10

Pricing emissions by extending environmental taxes and removing harmful exemptions......................10

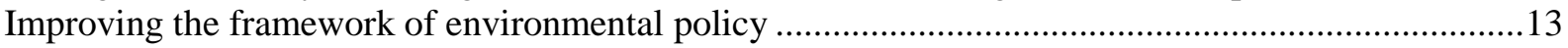

Selecting the most cost efficient tools to foster environmental-friendly activities ................................15

Developing green sources for long-term growth and adapting to a greener economy ..............................17

Eco-innovation as the key to address the challenges posed by a greening economy ..............................17

A framework for eco-innovation needs to be created ............................................................................18

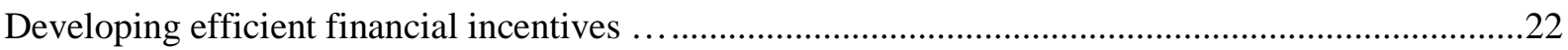

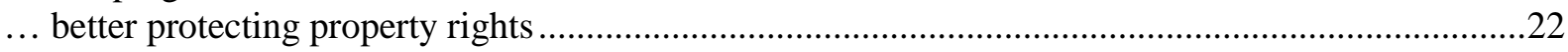

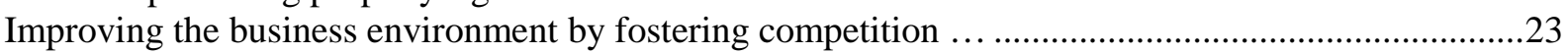

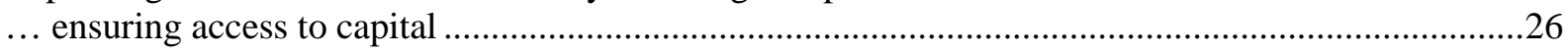

... improving labour mobility and skills availability .........................................................................26

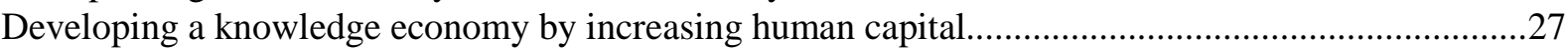

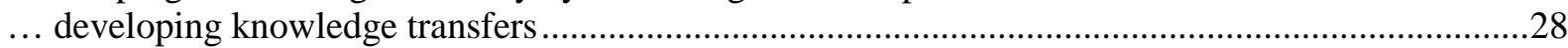

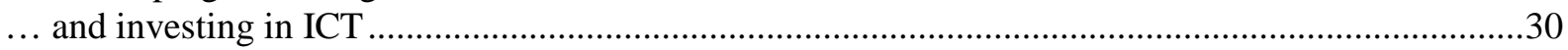

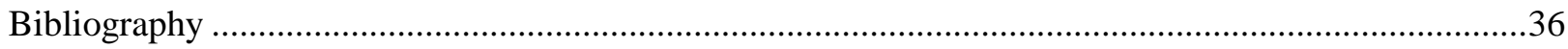

Annex 1. Energy efficiency gains and rebound effects...........................................................................39

\section{Boxes}

Box 1. National measures to develop renewable energy sources (RES) …............................................14

Box 2. Public support for innovation and business R\&D in Slovakia ................................................21

Box 3. Competition and innovation in the energy market .......................................................................25

Box 4. Recommendations for a transition to greener growth .................................................................32

Disclaimer: This document and any map included herein are without prejudice to the status of or sovereignty over any territory, to the delimitation of international frontiers and boundaries and to the name of any territory, city or area. 
ECO/WKP(2011)74 
ECO/WKP(2011)74

\title{
REAPING THE BENEFITS OF A TRANSITION TO GREENER GROWTH IN SLOVAKIA
}

\author{
By Caroline Klein ${ }^{1}$
}

Slovakia, as a catching-up economy, has to pursue strong economic growth, while preventing environmental degradation and unsustainable natural resource use. In short: to "grow green". In particular, reducing greenhouse gas (GHG) emissions and energy intensity will be essential to limit the environmental damages of economic growth. Looking forward, environmental constraints and objectives - climate change mitigation in particular - is likely to lead to substantial global economic transformations. The transition to a greener economy supported by international environmental commitments and national policies will entail structural changes in consumption patterns and industry structures resulting in a reallocation of resources in and between countries.

Implementing policies aiming at achieving these environmental goals and ensuring a smooth transition is particularly challenging for Slovakia. Its economy is highly dependent on price competitiveness and specialized in energy-intensive industries and car production. Slovakia will need to build an effective framework for green growth to limit the cost of the transition but also to maximise the chances of exploiting cleaner sources of growth, and seize the opportunities to develop new green industries, jobs, and technologies. This requires setting up a broad range of economic instruments to address environmental externalities and implementing structural reforms to improve the eco-innovative and adaptive capacities of the economy.

This paper first analyses the climate change policy framework in Slovakia, focusing on options to improve its cost-efficiency. In a second part, reforms which would help Slovakia to reduce the cost related to this transition, notably by fostering eco-innovation and exploit environmentally friendly sources of growth are discussed.

\section{Climate change mitigation and increasing energy efficiency are two major challenges}

\section{GHG emissions have been reduced since 1990 ...}

Slovakia overachieved the objectives determined in the Kyoto Protocol by decreasing significantly GHG since 1990. The decline in GHG emissions is the highest among OECD and Visegrad countries, with average emissions 35\% lower than the 1990 base-year level in 2008, well below the Kyoto target of an 8\% decrease for the period 2008-12 (Figure 1). Between 1990 and 2007, these reductions were observed in almost all sectors with a decoupling of GHG emissions from economic growth (Figure 2) (EAA, 2010). ${ }^{1}$

1. Caroline Klein is economist in the Economics Department of the OECD. This paper is based on work originally prepared for the 2010 Economic Survey of the Slovak Republic published on 25 November 2010 under the authority of the Economic and Development Review Committee (EDRC). More details on the issues covered in this working paper are available in the 2011 OECD Environmental Performance Review of the Slovak Republic. The author would like to thank OECD staff members Felix Hüfner, Andreas Wörgötter, Nils-Axel Braathen, Robert Ford and Andrew Dean for valuable comments on an earlier version but retains full responsibility for any errors or omissions. The paper also benefitted from discussions with experts of the Slovak Ministries of Finance, Economy and Environment. Thanks to Béatrice Guérard for excellent research assistance and to Josiane Gutierrez for technical preparation. 
The main reduction in GHG emissions was in the 1990s, while the pace of decrease slowed and stabilized around $-0.1 \%$ annually between 2000 and 2008 .

Figure 1. Growth in greenhouse gas emissions between 1990 and 2008

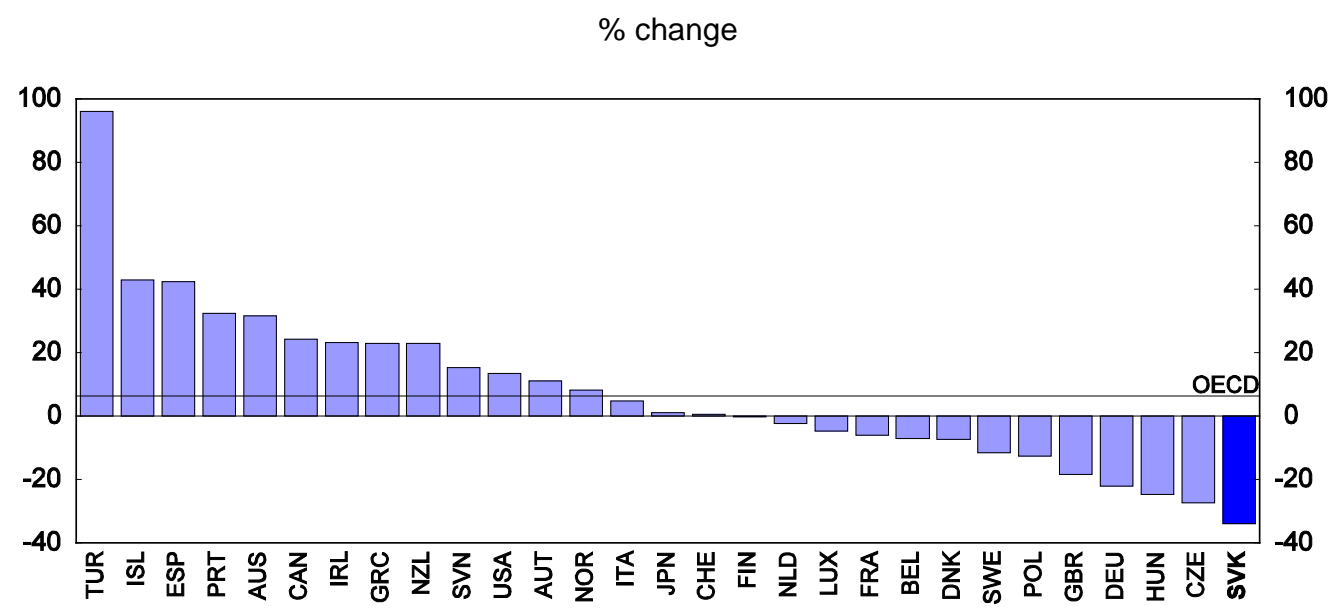

Source: United Nations Framework Convention on Climate Change (UNFCCC), Greenhouse Gas Inventory Data.

Figure 2. Greenhouse gas emissions per unit of GDP over time

Tons $\mathrm{CO}_{2}$-eq/thousand PPPs USD

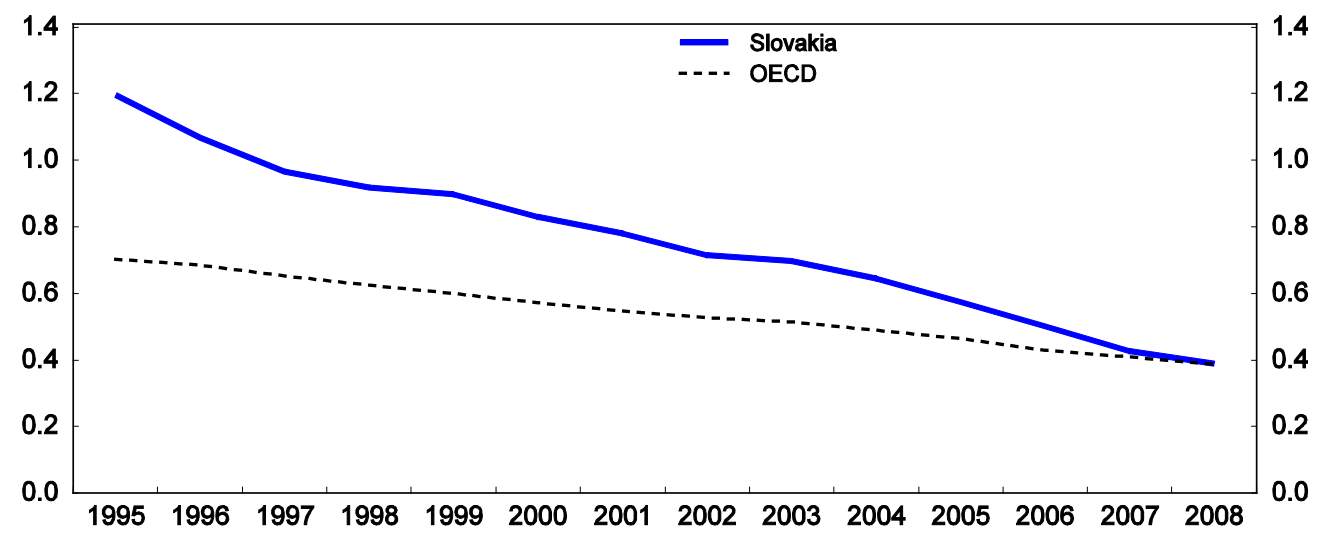

Source: UNFCCC and OECD Economic Outlook Database.

Several factors played a role in Slovakia's reduction in GHG emissions (Slovak Hydrometeorological Institute and Ministry of the Environment of the Slovak Republic, 2009). The sectoral composition of the economy changed as the share of services in GDP increased. The energy mix evolved towards less polluting energy sources, switching from liquid and solid fossil fuels to natural gas fuels. Energy consumption declined in some energy-intensive sectors, except for metallurgy. On the national level, energy intensity decreased by one half between 2000 and 2008, the highest decline in the OECD. ${ }^{2}$

These changes are partly explained by the structural transformation of the economy since the 1990s. The transition shock led to the closure of many energy wasting and inefficient units. Market reforms created a better business environment with increasing competition, contributing to a more efficient allocation of energy resources and reducing production costs. The opening up to foreign investment and 
measures improving the attractiveness of Slovakia as an investment location facilitated the diffusion of technologies. Innovation in green technologies and energy-efficient processes had thus enlarged the possibilities for reducing energy use. In addition, legislative measures - including to meet international commitments - influenced directly or indirectly the generation of GHG emissions via the change in the energy mix and technological restructuring. ${ }^{3}$ By contrast, the contribution of the EU Emissions Trading Scheme (ETS) to the GHG reduction was small because of the over-allocation of permits relative to the level of GHG emissions. In 2009, emissions represented 67\% of the allocated allowances in Slovakia, while they accounted for $95 \%$ on average in the EU27. Finally, the change in relative energy prices, notably through the removal of energy price subsidies and the increase in oil prices might have encouraged a reduction in energy consumption and energy waste.

\section{... but still remain high due to high energy intensity}

Nevertheless, Slovakia ranks among the ten most GHG-intensive economies in the OECD (Figure 3). In 2008, GHG emissions as a share of GDP were $30 \%$ higher than in the average EU20 country (Table 1). ${ }^{4}$ In addition, the pace of reduction in GHG emissions has slowed significantly and GHG emissions will probably grow in the coming years if no additional measures are implemented. This reflects the increase in economic growth and in the marginal $\mathrm{CO}_{2}$ abatement costs, which tend to rise with the level of emissions reduction. ${ }^{5}$ Some projections indicate that the environmental measures announced by the government will not be sufficient to limit the expected rise in GHG emissions (EEA, 2009).

Figure 3. Greenhouse gas emissions per unit of GDP across OECD countries 2008, tons $\mathrm{CO}_{2}$-eq/thousand PPPs USD

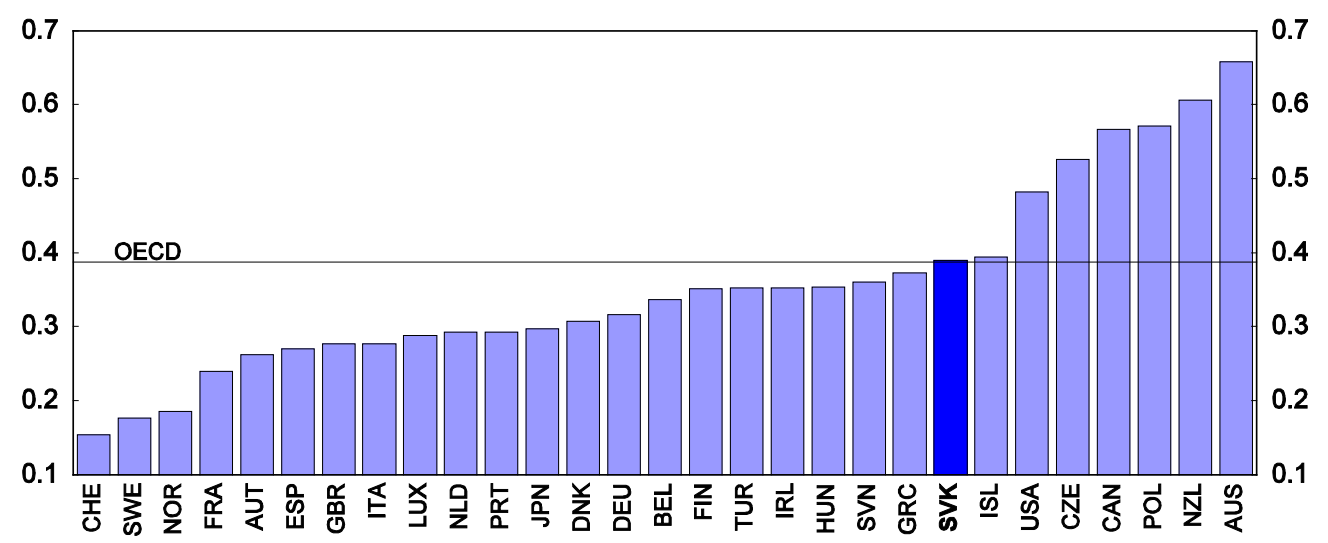

Source: UNFCCC and OECD Economic Outlook Database. 
Table 1. Decomposition of GHG emissions trends (level in 2008)

\begin{tabular}{lrrr}
\hline & GHG/GDP & $\begin{array}{c}\text { Energy } \\
\text { consumption/GDP }\end{array}$ & \multicolumn{2}{c}{ GHG/ } \\
Czech Republic & 525.5 & 100.3 & 5.2 \\
\cline { 2 - 4 } Hungary & 353.4 & 89.8 & 3.9 \\
Poland & 571.4 & 94.6 & 6.0 \\
Slovakia & 389.3 & 94.1 & 4.1 \\
OECD & 386.6 & 90.3 & 4.3 \\
EU20 & 302.6 & 76.3 & 4.0 \\
\hline
\end{tabular}

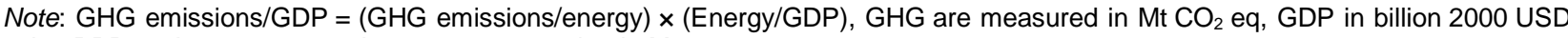
using PPP exchange rates and energy consumption in Mtoe.

1. EU20 is an aggregate covering countries that are members of both the European Union and the OECD. These are the EU15 countries plus Czech Republic, Hungary, Poland, the Slovak Republic and Slovenia.

Source: UNFCCC, IEA and OECD calculations.

Energy intensity is the main factor behind GHG emissions ...

Energy intensity is the main determinant of the high level of $\mathrm{CO}_{2}$ emissions. Despite a significant decrease since 1990, it is significantly above the OECD and the European averages (Table 1). Energy-intensive industries, such as steel, petro-chemicals and cement, account for a relative high share of GDP compared to the OECD average (Figure 4). In these energy-intensive sectors, the weight of energy in total expenditures is above the euro area average (ECB, 2010). For example, in the chemical industry, energy spending accounts for more than $20 \%$ of total expenditures compared to less than $10 \%$ in the euro area. Basic metal and transport sectors are also more energy-intensive. This may indicate that the sectoral composition of the economy is not the only factor behind the high energy intensity and that energy efficiency could still be improved in energy-intensive sectors. ${ }^{6}$

Figure 4. Share of energy-intensive industries and the service sector

Per cent of total value added in 2008 or latest year ${ }^{1}$

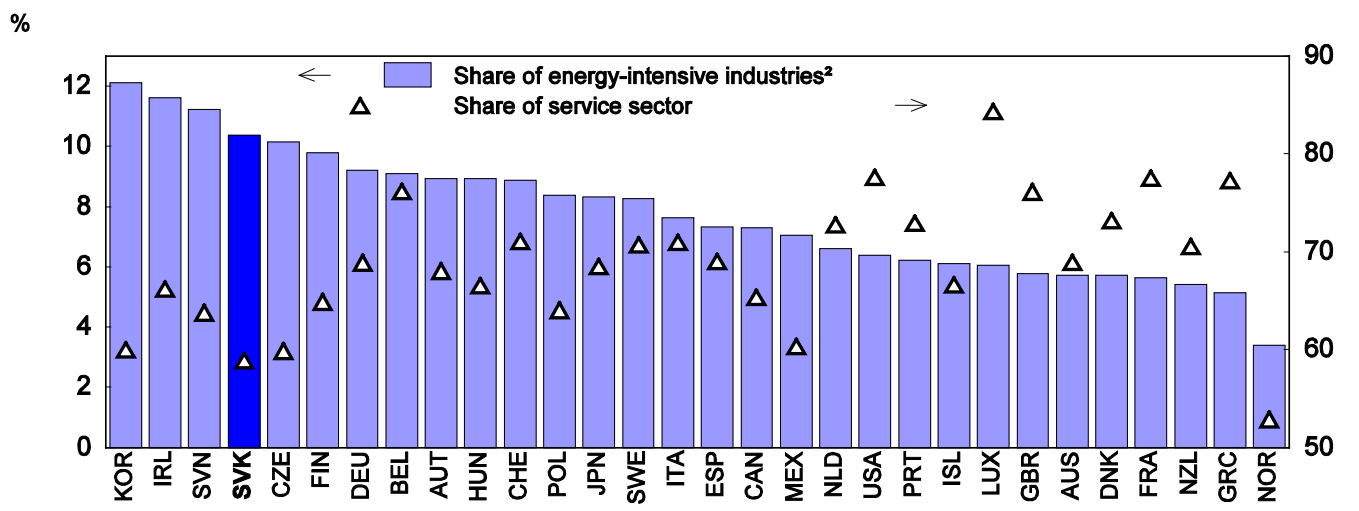

1. The data are for 2007 for Germany, Poland, United Kingdom and the United States, 2006 for Japan, New Zealand and Portugal, and 2005 for Australia and Canada.

2. Energy-intensive industries are defined as ISIC 21-28.

Source: OECD, STAN Database. 


\section{... while the energy mix is favourable}

The high level of GHG emissions does not reflect an unfavourable energy mix. Total energy supply is characterized by high shares of low carbon-intensive energy sources, such as nuclear and gas (Figure 5). ${ }^{7}$ While renewable energy sources (RES) remain underdeveloped, Slovakia benefits from large nuclear capacities and consumes relatively more natural gas than oil. $\mathrm{CO}_{2}$ emissions per kWh produced from different energy sources are also lower in Slovakia compared to the OECD average. ${ }^{8}$

\section{Figure 5. Total primary energy supply}

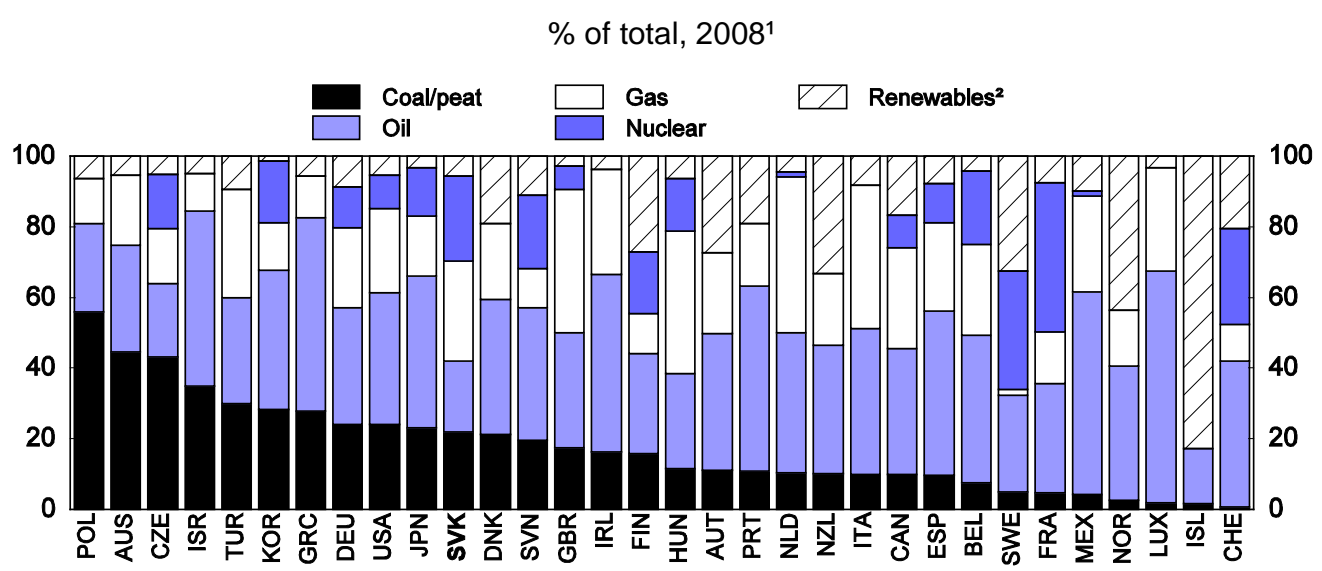

1. The total excludes electricity and heat.

2. Hydro, geothermal, combustible renewables and waste, and solar/wind/other.

Source: IEA (2009), Energy Balances of OECD countries and Energy Balances of non-OECD countries.

In 2008, the government planned in their Energy Security Strategy to develop new nuclear capacities and maintain the proportion of electricity produced from nuclear sources at no less than $50 \%$. The development of nuclear energy is an effective way to reduce the carbon intensity of the energy supply. It could also ensure a certain level of energy supply security, reducing the negative energy balance and lowering dependency on coal, natural gas and crude oil imports which are high in Slovakia: in 2008 around 64\% of energy supply was imported (IEA, 2010). In particular, the country is highly dependent on gas imports from Russia: gas represents around $28 \%$ of total energy supply and $98 \%$ of gas is imported from Russia. In January 2009, Slovakia was severely affected by the gas supply disruption during the Russia-Ukraine dispute, which resulted in production cuts. Slovakia is also a net importer of nuclear fuel but this dependency is potentially less damaging than gas. This is because nuclear fuel provision does not depend on international distribution networks and fuel costs remain only a small fraction of the cost of electricity generated in nuclear power plants (IEA, 2008). Investment in nuclear energy should be thus fostered, although the safe management of radioactive waste needs to be ensured.

\section{Reducing GHG emissions and energy intensity is highly desirable ...}

A rapid and significant improvement in energy efficiency would contribute to creating sustainable conditions for economic growth. By potentially reducing the level of GHG emissions, it would ease global climate change mitigation efforts, which are highly desirable from an economic and social point of view. ${ }^{9}$ Energy efficiency would also lessen environmental damages of economic activity by limiting the local environmental damage related to energy consumption. In addition, a decrease in energy intensity would facilitate the fulfilment of the current and future international environmental commitments. In particular, Slovakia has to reach the European 20-20 targets defined in the Climate Energy Package, i.e. to limit the 
increase in GHG emissions to 13\% relative to the 2005 level, increase energy consumption from renewable resources to $14 \%$ of total energy consumption and save $11 \%$ of the final energy consumption relative to the average of 2001-05 by 2020 .

In addition, better environmental performance would also have beneficial economic effects for Slovakia. Reducing energy intensity increases the energy supply security and lowers the dependency toward fossil fuel imports. Energy savings would also limit the adverse economic effects on inflation, competitiveness and potential output expected from a shortfall in the primary energy sources and rising energy prices. ${ }^{10}$ The potential gain in reducing energy intensity in Slovakia is particularly high: its level of energy intensity makes inflation more sensitive to an increase in oil prices than in other countries: an increase of $10 \%$ in oil prices leads to an increase of producer prices of $0.78 \%$ in Slovakia compared to $0.39 \%$ in EU27 (ECB, 2010). Finally, energy savings could also create room for investment and hence development of new sources of growth.

\section{... and requires a broad range of policy measures}

Reducing GHG emissions and energy intensity requires a vast range of reforms and a mix in policy instruments (de Serres et al., 2010). The Slovak authorities have tended to concentrate their efforts on the improvement of energy efficiency and the development of cleaner energy sources (renewables and nuclear power). However, increasing energy efficiency is not sufficient to limit the rise in energy consumption and subsequent GHG emissions: efficiency gains lower the relative price of energy and raise the disposal income of consumers which may lead to wasteful behaviours and result in an increase in energy demand. These potential "rebound effects" (or "take back effects") may limit the benefits expected from an increase in energy efficiency (Annex 1). In consequence, the scope of the Slovak environmental policy needs to be broadened beyond improvement in energy efficiency. Energy and environmental policies should aim at developing incentives for energy savings and discouraging environmentally harmful activities. Emphasis should also be put on the cost-efficiency of measures, not least because urgent fiscal consolidation is needed (OECD, 2010f).

\section{Addressing the challenge of making economic growth more environmentally sustainable}

\section{Pricing emissions by extending environmental taxes and removing harmful exemptions}

Pricing pollution is a cost-effective way to limit negative environmental externalities by discouraging environmentally harmful behaviour. Introducing taxes on pollution or a pollution trading system provides incentives to reduce energy demand, to invest in less carbon-intensive energy sources, to limit waste, and to use technologies that limit emissions. In particular, environmentally-related taxes tend to foster the diffusion and adoption of innovative technologies, even for firms which do not have the resources to undertake R\&D activities (OECD, 2010a). For example, in Sweden, the rate of adoption of the abatement technology for $\mathrm{NO}_{\mathrm{x}}$ emissions increased from $7 \%$ to $62 \%$ in the two years after the introduction of a tax.

These market-based instruments encourage the selection of cost effective options for pollution abatement and at the same time provide revenues which could replace more distorting taxes. In the short and medium run, the price elasticity of pollution and energy demand is low as finding solutions to reduce pollution and energy use needs time. In consequence, during this period, the revenues raised by taxation may be high. In the long run, revenues from environmental taxation may decrease due to changes in consumption behaviour and pollution reduction and thus should not be considered as permanent revenue sources. However, changing the structure of the taxation system by increasing environmental taxes could permanently benefit economic growth as environmental taxes are less distortive than taxes on capital and labour. Recycling environmental tax revenues in lowering more harmful taxes would limit the adverse 
effect of taxation on the less polluting firms and limit the losses of competitiveness for polluting firms without removing the incentives for pollution abatement.

Slovakia already uses market-based instruments for environmental purposes. Regarding climate mitigation, as a member of the European Union, Slovakia participates in the EU Emissions Trading System (ETS). An environmentally-related taxation system (including taxes and charges on air pollution, water pollution, waste management, noise, energy products, transport, and resource exploitation) covers some sources of pollution and sectors not covered by the EU ETS. The revenues from environmental taxation accounted for 2.2\% of GDP in 2008, just above the OECD average of 2.1\% (Figure 6). ${ }^{11}$ Taxes include excise duties on oils (82\%), other energy taxes (1\%), taxes on motor vehicles and transports (7\%) and taxes on other polluting activities (waste disposal, GHG emissions).

Figure 6. Environmental tax revenues

$\%$ of GDP

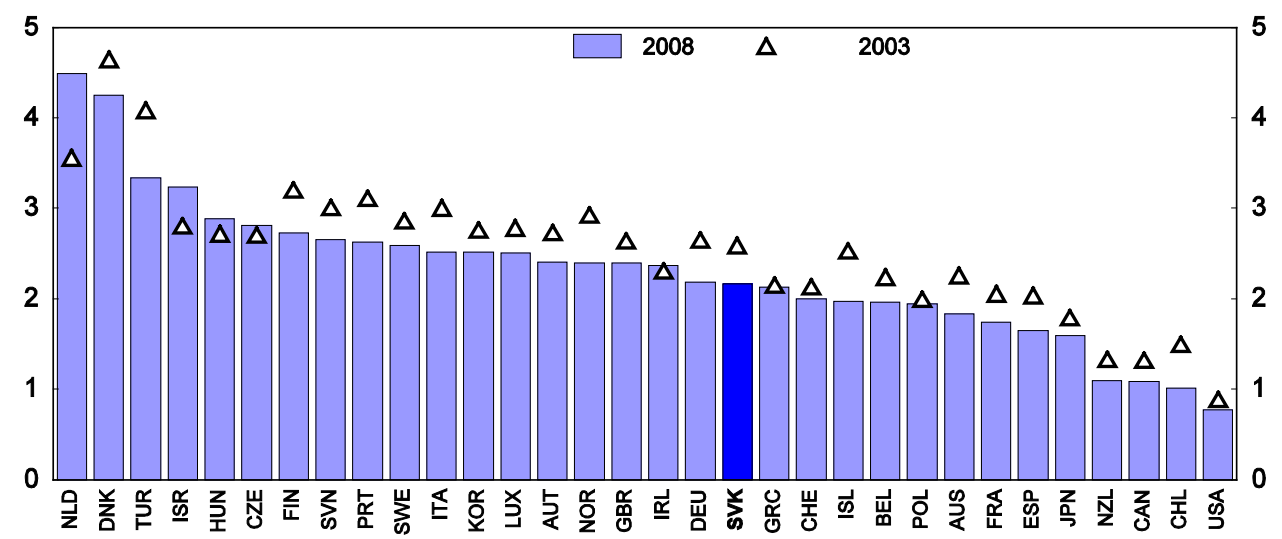

Source: OECD/EEA, Database on Instruments for Environmental Policies.

The weight of environmental taxes in GDP has decreased over the past few years, mostly due to a drop in revenues from excise duties on oil. Oil consumption declined as a result of taxation of oil and the rise in crude oil prices: oil supply as a percentage of GDP (toe per thousand 2000 USD) accounted for 0.11 in 2008 against 0.14 in 2003 (IEA, 2009). This decrease is not observed in the transport sector as, contrary to other OECD countries, the use of motor fuels remained broadly stable as a share of GDP. The initial relatively low level of oil consumption and the underdevelopment of the transport sector may partly explain this evolution. The increase in prices might have limited the development of road transportation. However, the taxation of oil has been insufficient to foster the development of alternative transportation. The absence of alternatives for transportation could also justify the low price elasticity of oil demand in this sector. To improve the effectiveness of taxes on oil and motor vehicles in reducing air pollution and $\mathrm{CO}_{2}$ emissions, the development of alternative transportation means should be fostered. In doing so, greater scope for private suppliers of seek alternatives should be provided.

Revenues from energy taxes could be raised. Even if energy prices are above the OECD average (IEA, 2009), the implicit tax rate on energy is the lowest in the EU (Figure 7). ${ }^{12}$ In addition, the share of non-oil energy taxes (i.e. excise taxes on coal, natural gas, and electricity) in total environmental tax revenues is currently low. This is partly due to many exemptions and reduced tax rates. Notably, exemptions exist for electricity, gas and coal used by final household customers, for electricity used in certain industries (if the costs of electricity represent more than $50 \%$ of the average own costs of the product manufactured), and for electricity and gas used for the transportation of persons and cargo by 
public transport (e.g. trains, underground, tramways). Also, the tax rate on diesel used in rail and electricity production is reduced.

Figure 7. Implicit tax rate on energy

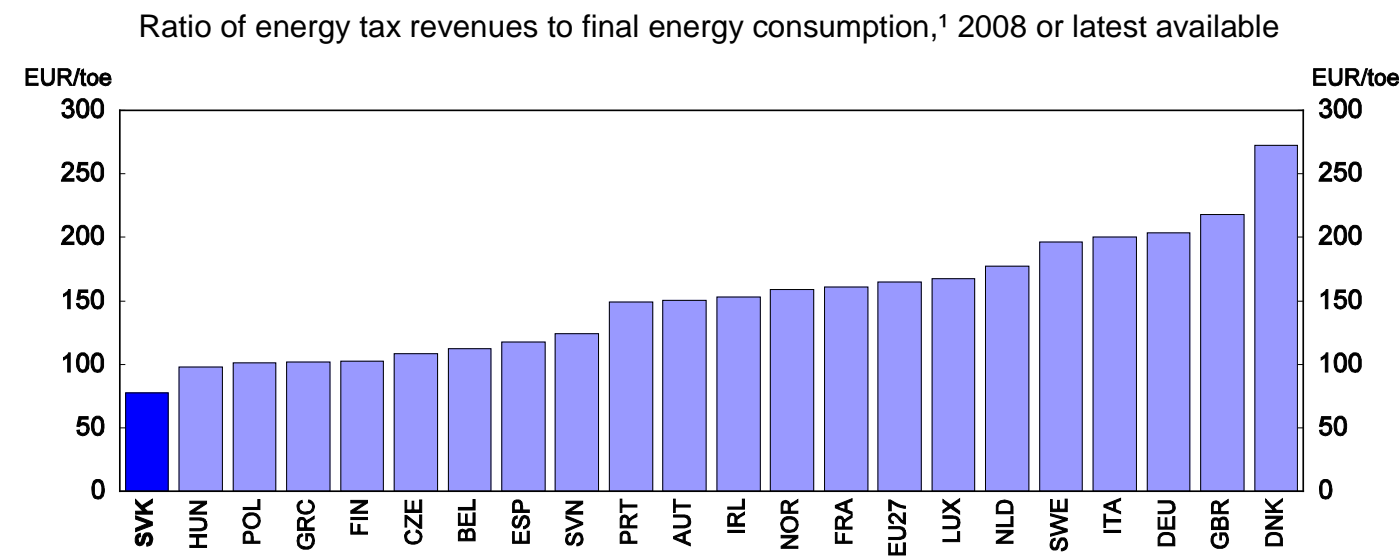

1. The implicit tax rate is measured as the ratio between the energy tax revenues (taxes levied on the use of energy in EUR thousands) and final energy consumption (thousands tons of oil equivalent).

Source: Eurostat.

Such exemptions have adverse environmental effects and lead to a misallocation of resources. As they suppress the price signal created by the tax, they encourage wasteful consumption, provide incentives to develop or maintain energy-consuming technologies and impede investment in clean energy sources. Removing these tax exemptions could significantly support the climate change mitigation effort and provide potential revenue gains of EUR 120 million, around 9\% of total environmental tax revenues or $0.2 \%$ of GDP. Thus, the removal of several tax exemptions, such as exemptions for natural gas and coal used for heating, approved by the government is welcome. The objectives pursued by the exemptions could be achieved through alternative instruments that could raise both economic efficiency and environmental outcomes. The exemptions designed for households implemented for social reasons are counterproductive: they are not targeted and give greater benefit to rich households who consume more energy. They should be replaced by targeted cash transfers, compensating for the cost of the taxation, but not linked to energy consumption. The exemptions offered to energy-intensive industries are inefficient as they could encourage firms to increase their energy consumption over the $50 \%$ ceiling required to qualify for the exemption. Well-targeted and time-limited compensation could be offered to energy-intensive industries to offset the financial loss related to the increase in taxation and ease the transition towards higher energy costs. The reduced tax rate in the rail and water transport sectors is implemented to foster the development of alternative transportation which could lead to a decrease in oil consumption. The development of these sectors could be encouraged by increasing taxation on polluting transportation means or at least by replacing the reduced tax rate by direct subsidies to avoid encouraging energy inefficient technologies.

Slovakia also has room to increase environmental tax revenues by creating new taxes and raising tax rates. The share of environmental taxation in total tax revenue (around 7.7\%) is above the OECD average but could be extended: for instance, in 2008, environmental taxes account for respectively $12 \%$ and $14 \%$ of total tax revenues in the Netherlands and in Turkey. The low level of non-oil taxes compared to other OECD countries also suggests margins for the development of environmental taxation. For example, the government should consider increasing the tax rate on $\mathrm{NO}_{\mathrm{x}}$ which is quite low in international comparison (OECD, 2010a). In addition, a carbon tax should be set up in those sectors not covered by the EU ETS. This measure would allow a unique price to be put on GHG emissions, thereby limiting distortions across sectors and minimizing the cost of reducing emissions by equalising marginal abatement costs across all emitters. Establishing a tax is less costly than setting up regulation or extending an ETS when technical or 
measurement problems make the monitoring of emissions difficult, mostly when sources are small and diffuse (e.g. households). It also spares the information costs related to regulation changes and is easy to implement. To be efficient, carbon taxes should be transparent, predictable and credible to encourage firms to invest and innovate in green technologies in the long run. They should not replace other taxes, such as oil taxes or motor vehicle taxes, to the extent these taxes are not addressing externalities related to carbon pollution (but aim at other purposes, such as financing public infrastructures or limiting other sources of air pollution).

Environmental taxation could also be extended by introducing an environmental dimension in the motor vehicle tax. This tax is currently levied on vehicles used for business purposes depending on vehicle weight and the number of axles for trailers and on the engine cylinder capacity in cubic centimetres for passenger vehicles. The taxation should be broadened to all vehicles and improved by switching the tax base to $\mathrm{CO}_{2}$ emissions and energy consumption of the vehicles so as to encourage consumers to buy environmentally friendly vehicles. As this measure disadvantages low income households unable to change their cars, a gradual phase in should be considered.

\section{Improving the framework of environmental policy}

Apart from environmental taxation, Slovakia's energy and environmental policies are largely based on legislative changes - often due to EU commitments - and the provision of subsidies financed by national and EU structural funds. Public expenditures allocated to environmental protection accounted for $1.8 \%$ of total public expenditures in 2008 which is comparable to the OECD average (Figure 8). Besides, environmental protection is one of the main priorities for the use of EU-funds between 2007 and 2013 (OECD, 2010f). The environment operational programme accounts for EUR 1.8 billion (2.7\% of GDP), which is approximately $15.5 \%$ of the total EU money invested in Slovakia under the Cohesion Policy for 2007-13 (second after the operational programme for transport). It focuses mainly on protection and rational utilisation of water ( $51 \%$ of the allocated funds), but also includes programmes for waste management, flood prevention and air protection.

\section{Figure 8. Share of public expenditures allocated to environmental protection}

$\%$ of total public expenditures, 2008 (or latest available) ${ }^{1}$

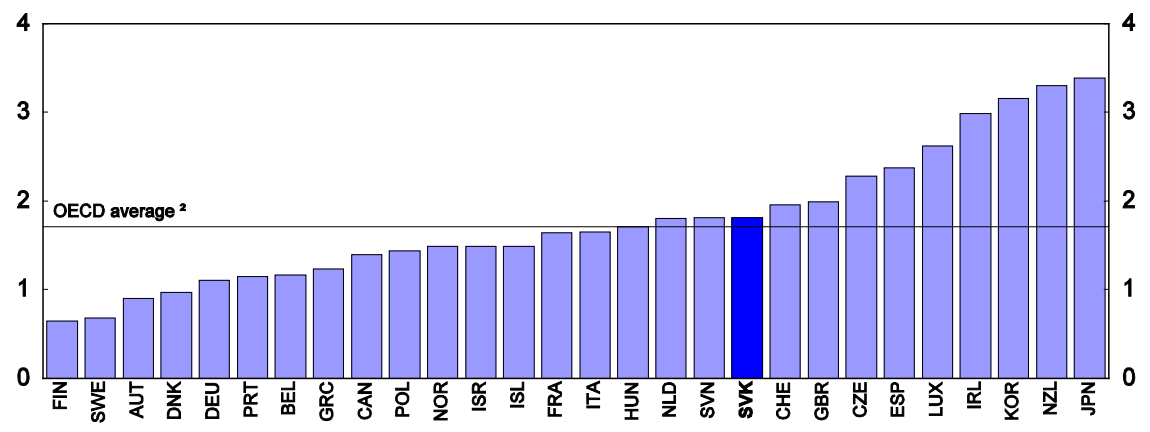

1. 2007 for Iceland, Japan and Switzerland; 2006 for Canada and 2005 for New Zealand.

2. Excludes Australia, Chile, Mexico and Turkey.

Source: OECD, National Accounts Database.

Regarding energy efficiency, Slovakia established the National Energy Efficiency Action Plan 2008-10 (1NEEAP) in 2007. This programme aimed at saving 3\% of energy by 2010 and $9 \%$ by $2016 .{ }^{13}$ It includes horizontal measures, such as the establishment of monitoring capacity, the launch of information campaigns, the introduction of energy efficiency criteria in public procurement, and more sector specific policies, notably in the building sector, such as the provision of preferential loans for the thermal insulation of buildings. The total budget for implementation of the energy efficiency measures covered by the 
1NEEAP is to be EUR 72.6 million, about $0.1 \%$ of GDP (including EU funds). As the 1NEEAP is currently being evaluated by the Ministries in charge of its implementation, the total investment into these energy efficiency measures and their outcomes remain unknown.

Slovakia also implements programmes to develop RES. RES accounted for $6.7 \%$ of gross final energy consumption in 2005, which should increase to $14 \%$ in 2020 according to the EU commitments (Directive 2009/28/CE). In 2009, the Slovak government introduced new renewable energy legislation and increased the use of subsidies to foster the development of RES (Box 1).

\section{Box 1. National measures to develop renewable energy sources (RES)}

The national measures aiming at developing RES are mostly subsidies and tax exemptions, notably:

- Feed-in tariffs for electricity production from RES and from high-efficiency cogeneration (combined production of electricity and heat) were introduced in the electricity sector in January 2006 and reformed in 2009. Electricity distributors commit to purchase power from RES at a fixed price above the market price. The tariffs are guaranteed for 15 years and defined by the RONI (Regulation Office for Network Industries). In addition, the RES electricity producers benefit from a preferential access to the network (connection to the regional distribution system, access to the system, transmission, distribution and supply of electricity) and have the priority to sell their production to energy distributors.

- Slovakia has been allocating subsidies to develop biomass and solar energy production since 2009 . The Programme for Promotion of Biomass and Solar Energy Use in Households is providing state aid for the installation of biomass generated boilers or solar collectors.

- The environmental taxation system includes tax exemptions to foster the use of clean energy sources notably on bio-fuels, on Liquefied Petroleum Gas (LPG), on electricity generated from a renewable source or combined generation of electricity and heat, on electricity, gas and coal used in combined generation of electricity and heat, and on gas designated for the production of compressed natural gas used as a motor fuel.

- In 2006, a regulation intended to promote bio-fuels to ensure the transposition of the EU Directive on bio-fuels (Directive 2003/30/EC). By 31 December 2010 bio-fuels should account for $5.75 \%$ of the total quantity of petrol and diesel fuel (measured on the basis of energy content).

- Additional measures are planned in the draft of the National Action Plan for Renewable Energy (NAPRE), notably in the housing and the energy sectors. New regulations are considered, such as introducing an obligatory use of RES in new and reconstructed buildings and in heating/cooling in public buildings, establishing a minimal share of heat supply from RES in district heating, and an amendment of legislation on urban planning and construction. Tax exemptions for RES heat production and for RES equipment are also being discussed.

The development and implementation of the Slovak environment and energy policies are not centralized and lack co-ordination. For example, several funds are devoted to the same objective, notably the improvement of energy efficiency in the housing sector and RES development. ${ }^{14}$ The multiplicity of funds and programmes seems to lead to an overlap in instruments and a misallocation of resources. While the drawing of EU funds in the environmental programme is particularly weak (OECD, 2010f), the requirements for a grant from the Environmental Fund exceed 10 to 12 times its financial capabilities. Some co-ordination efforts have been made recently; in particular, the Commission for the Climate Energy Package (CEP), involving all relevant ministries, has been established to prepare the implementation of the CEP and to develop a national strategy on climate change and RES. Co-ordination should be improved by reforming the framework of environment and energy policies, notably during the preparation of the second National Energy Efficiency Action Plan for 2011-13 (2NEEAP) and of the definitive action plan for the 
implementation of the CEP. The development, implementation and monitoring of these policies should be centralized and instruments and funds addressing the same issue should be merged.

Some regulatory barriers may also limit the efficiency of environmental measures and should be reconsidered. In particular, regulation in the solar and wind energy sector hampers the development of RES. The administrative rules for the construction of solar power plants have been tightened to ensure the security of the electricity transmission network. All investors have to obtain a certificate of compliance with the government's long-term energy policy to build a solar power plant (Amendment to the Energy Act in 2010). The rules behind the allocation of certificates lack transparency and should be clarified. Environmental legislation on protection of wildlife limits the development of wind power. Wind power represents a smaller share of RES production in Slovakia compared to neighbouring countries where there is simultaneously a large number of windmills installed, as well as a lot of attention for wildlife (e.g. Austria). This indicates that these environmental regulations should be reassessed, for instance by using international benchmarking.

\section{Selecting the most cost efficient tools to foster environmental-friendly activities}

Outcomes of the energy and environmental policies would also be improved by a systematic assessment of the instruments used. Evaluations are crucial to learn from past experiences, avoid shortcomings, and improve the information on the gains associated with the measures. In Slovakia, the environmental, budgetary and economic impacts of the proposed measures are not automatically considered during the determination of environmental and energy policies. Environmental and energy measures should be systematically evaluated ex ante and ex post. A first best would be to carry out costbenefit analyses considering indirect effects such as rebound effects, non-environmental benefits, and macroeconomic impacts (in particular the economic impact of the financing of the subsidies). However, as complete cost-benefit analyses may be costly, the government should at least implement national guidelines and devote capacities for the evaluation. During the evaluation, the cost-efficiency of the measures, the synergies with other policies and the distributional impact of policies should be assessed. Regarding ex post evaluation, measurable targets should be defined to ease the assessment of outcomes.

Also, limiting the use of subsidies could enhance the efficiency of Slovakia's energy and environmental policies. For policy makers, subsidies may be enticing instruments because they foster pollution reductions, increase demand in new sectors, create incentives to invest, and stimulate economic activity. However, subsidies are generally not cost effective compared to other market-based instruments. First, subsidies increase pollution abatement costs, particularly when the cost-efficiency of the subsidized technologies is low. Second, a high level of subsidies is costly to the budget. Third, the potential negative impact of the financing of the subsidies on the economy are important: financed by an increase in energy prices (e.g. feed-in tariffs) or by a rise in (distortive) taxes (e.g. subsidies financed by public funds), they may induce inflationary pressures, raise production costs, and reduce competitiveness. As a result, subsidies may deter economic activity even when their stimulating effect is taken into account. Many recent studies assessing the policies for the development of RES in OECD countries show that the costs of these policies largely overcome their environmental and economic gains (Lavecchia et al., 2010, for Italy; Cazalda et al., 2009, for Spain). Fourth, subsidies do not provide incentives to lower the pollution abatement cost and may divert investment from other low-emission technologies that could be more cost effective and thus hamper the development of new technologies.

In certain cases, however, the use of complementary subsidies could be appropriate to reach environmental targets on time. Market failures resulting in a weak response of agents to price signals can make market-based instruments inefficient for reducing effectively pollution and energy consumption and delay the effects of environmental and energy policies (de Serres et al., 2010). For instance, uncertainty about future pollution costs, energy prices, and development of technologies may hamper investments in 
green technologies (IEA, 2010). Imperfect information about the gains associated with investment could limit the demand for energy efficient or less polluting equipments. This effect is more important in certain sectors, where the energy cost is not decisive in economic choices as it represents a small share of the total cost or when the investments are irreversible (Geller et al., 2005). Limited access to credit may also hamper the adoption of energy efficient or low carbon technologies. This is particularly significant for low income households which may suffer from new regulation as they tend to not have access to the green technologies (because of a lack of disposal income or a limited access to credit and to information) and spend a higher amount of their revenues on energy. Numerous studies find that the discount rate for energy efficiency investment decreases with the level of the income (Geller et al., 2005). As subsidies are costly and as Slovakia needs to implement fiscal consolidation measures, those subsidies which can be replaced by other market-based instruments should be phased out. Subsidies should be used only to address specific and identified externalities. For instance, direct and targeted state aid should be implemented to ease access to clean energy for low income households.

Particular attention should be given to the measures to develop RES, i.e. feed-in tariffs, subsidies to get RES equipments and tax exemptions (see Box 1). Developing RES is less efficient than other climate change mitigation policies (e.g. a carbon tax or the EU ETS), as they force emission reduction to be realised through certain technologies. However, they are a way to decrease the dependence on imported energy and limit the resource shortages related to energy production. Furthermore, Slovakia as a member of EU has to reach an ambitious renewable target by 2020. Several reforms should be considered to improve the cost efficiency of RES policies in Slovakia. First, the interaction of these measures with other policies having an impact on GHG emissions (e.g. EU ETS) and encouraging the use of low carbon technologies should be taken into account. Pricing pollution creates incentives to develop clean technologies but should be complemented by other measures to orient energy consumers and producers towards RES. These measures should be cautiously monitored to avoid excessive $\mathrm{CO}_{2}$ abatement cost and deadweight losses due to a too high rate of return. In particular, regarding feed-in tariffs, experience in other countries suggests that care is needed in setting and monitoring the tariffs to prevent renewable energy production in which the additional cost over traditional energy production exceeds estimates of their benefits. ${ }^{15}$ In Slovakia, feed-in tariffs are high compared to the level of electricity prices (11 times higher in the case of solar energy) and may have lead to abusive investments. These tariffs should be revised, as planned by the government, by assessing their efficiency to achieve the RES goal in the least costly manner. Besides, the regulatory authority should consider adjusting the tariffs as a function of the technological maturity of equipment to encourage innovation and not distort the choice of abatement technologies. Second, tax exemptions on electricity produced from RES should be removed as feed-in tariffs already encourage the production of RES electricity and legislative rules ensure that electricity produced from RES is bought by distributors. Third, competition in the market for green technologies should be promoted to ensure a flexible supply response and efficient production (or importation). The efficiency of subsidies may be lowered by crowding-out effects if supply for green technologies and equipments is underdeveloped, as an increase in demand may create supply shortages and increase prices. Fourth, subsidies supporting the installation of RES equipment by households should be reconsidered. As in the case of feed-in tariffs, the efficiency of this measure should be evaluated. For example, the question on whether the development of RES should be done on the household's level should be addressed. If promoting RES in households is set to be efficient, the framework of the policy should be revised. These subsidies aim at encouraging households to install RES equipment because the private return of the investment takes time to materialize, information on the potential gains of RES is lacking and some households cannot finance this investment. However, as mentioned above, these subsidies are potentially costly and may induce an increase in RES equipment prices. ${ }^{16}$ The recommended removal of exemptions on tax energy and the increase in environmental taxation should create incentives for households to invest in RES. This should be complemented by information campaigns on the gains related to RES production. Soft loans could replace subsidies to provide financing means to credit-constrained households. If the subsidies would be maintained, they should at least be better targeted on credit-constrained households. 
ECO/WKP(2011)74

\section{Developing green sources for long-term growth and adapting to a greener economy}

\section{Eco-innovation as the key to address the challenges posed by a greening economy}

Pollution mitigation policies and resource shortages will inevitably lead to an increase in energy prices and induced pollution abatement costs. In particular, in the EU ETS, from 2013, the number of allowances available to businesses will be progressively reduced, the free allocation of allowances will be gradually replaced by auctioning, and the sectors and GHG covered by the system will be expanded. As the EU ETS represents roughly half of total GHG emissions in Slovakia, the revision of the EU ETS will encourage a significant reduction of GHG emissions but also weigh on the costs of production. ${ }^{17}$

The potential losses in competitiveness may be significant when the country, like Slovakia, is specialized in sectors for which the price elasticity for the goods produced is high or in sectors which are energy intensive. In particular, energy intensive sectors (especially steelmaking) are highly competitive and firms have no margin to pass-through an asymmetric increase in production costs on their final prices. The Slovak automotive sector could also be affected by the greening of the economy: rising oil and carbon prices may reduce automotive demand and change the specialization of the automotive industry towards less energy consuming cars.

Slovakia has to prepare for such structural changes as it risks losing market shares in its sectors of specialization. Losses of competitiveness would be limited by the recycling of environmental taxes and expected gains in energy efficiency. Besides, environmental policies may even affect competitiveness in a positive way, by encouraging efficiency gains and productivity growth (OECD, 2009a). Nevertheless, the risks remain high and the sectoral or distributional effects of a greening economy should be anticipated to set up a comprehensive strategy for economic growth. For example, a challenge for Slovakia, confronted by the change in the automotive industry, is skill shortages since producing new car types would require more qualified labour. The energy-intensive and the automotive industries employ primarily non skilled workers who will have difficulties to adapt to changes in qualification requirements.

In addition, to limit the cost of the transition to a low-carbon economy, Slovakia will have to access and adopt new green technologies. Even if technological innovation for climate change mitigation developed a lot between 1978 and 2006 (OECD, 2010b), the technologies and processes needed to reduce emissions and ensure environmental sustainability are still lacking (Aghion et al., 2009). ${ }^{18} \mathrm{R} \& \mathrm{D}$ and innovation activities for environmental purposes are likely to develop on the global level as economic benefits related to environmental innovations are significant. They may foster the development of new sectors for which demand is potentially high. In this context, Slovakia should improve the adaptive capacity of its economy to adjust to this moving technological frontier. It should also find ways to lower the purchase cost of these technologies.

Developing a framework for eco-innovation - i.e. implementing new, or significantly improved, products (goods and services), processes, marketing methods, organisational structures and institutional arrangements which lead to environmental improvements compared to relevant alternatives - is an effective way to address these economic and environmental challenges. ${ }^{19}$ First, eco-innovation is needed to integrate the green technologies into the national framework (e.g. create infrastructures for smart grid) and to adapt to new environmental constraints (e.g. find organisational solutions to limit wasteful use of resources at the firm level). Second, fostering eco-innovation would ease the transition toward a greener economy as it induces reforms which improve the overall functioning of the economy and the economy's adaptability to structural change. Finally, eco-innovation creates new sources of growth by fostering the development of new sectors and new knowledge. This is crucial for Slovakia as it emerges from the crisis and needs to pursue further its catching-up process. Slovakia cannot just rely on its competitive advantage of low labour costs to drive its economic development. Competition from neighbouring and emerging countries is likely 
to intensify and Slovakia will have to find new sources of competitiveness so as to maintain its attractiveness as a place of investment. Besides, future growth will rely on its capacity to increase the performance of domestic firms and to raise gradually the autonomy of its economy from foreign investments.

Fostering eco-innovation requires implementing structural reforms to foster general innovation capacity rather than targeting R\&D efforts on specific fields (OECD, 2010c). Innovation does not rely exclusively on R\&D activities and only a very small percentage of green technology patents between 2000 and 2007 draw on environmental or energy R\&D (OECD, 2010b). It rather requires implementing a broad range of reforms, involving measures to support innovation and $R \& D$ spending as well as improving the business environment and human capital formation. These policies are complementary and need to be co-ordinated. The urgent need for fiscal consolidation should not delay their implementation but instead promote a cost-effective implementation.

\section{A framework for eco-innovation needs to be created}

Slovakia is among the countries with the lowest performance in innovation in international comparisons (OECD, 2010d). In 2008, the number of triadic patents and cross-border trademarks per capita was significantly lower than the OECD average and only a low percentage of firms had innovation activities (Figure 9). Slovakia is a net technology importer: expenditure on foreign technology (technological payments) is greater than expenditure for domestic business enterprise R\&D (Figure 10). ${ }^{20}$

Figure 9. Science and innovation profile of the Slovak Republic

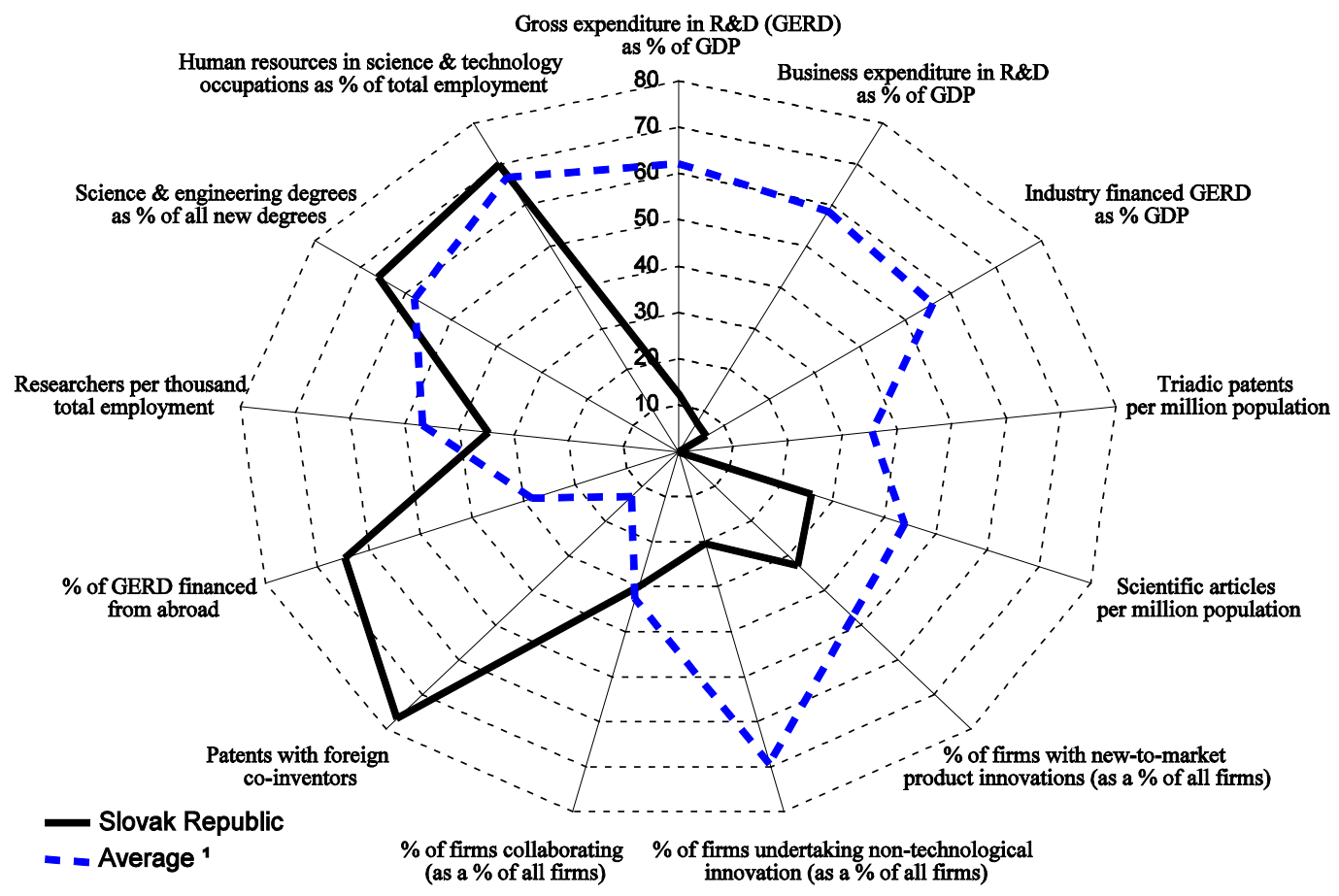

1. OECD countries where the data are available, excluding Chile and Slovenia.

Source: OECD, Science, Technology and Industry Outlook 2010. 
Figure 10. Technology balance of payments

$\%$ of GDP, 2008 or latest available ${ }^{1}$

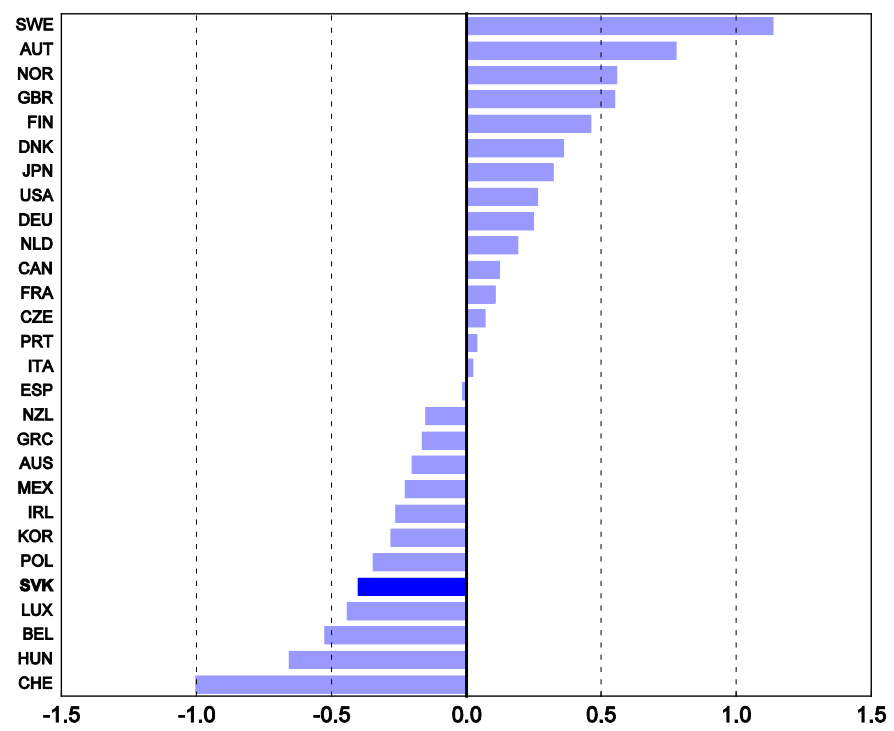

1. 2007 for Canada, Korea and Switzerland; 2006 for Denmark, Netherlands, New Zealand and the Slovak Republic; 2005 for Mexico and 2003 for France.

Source: OECD, Main Science and Technology Indicators Database and Economic Outlook Database.

The general level of R\&D is also low relative to other OECD and Visegrad countries. Despite a recent increase in public R\&D spending, total gross expenditures on R\&D (GERD) are the second lowest in the OECD (0.5\% of GDP in 2008) (Figure 11). Compared to the public sector, the business sector plays a small role in the national R\&D system. Only $40 \%$ of R\&D activities are performed in the business sector (against 70\% in the OECD) and the share of industry funding in total GERD is significantly below the OECD average. In addition, Slovakia is the only OECD country which experienced a decline of business expenditures on R\&D in real terms during the last decade (almost 10\% per year) (OECD, 2009b). Efficiency of public R\&D spending to increase private R\&D performance is weak (Cincera, 2009). The fiscal stimulus to foster R\&D investment implemented in 2009 had little success; only 5\% of the allocated budget was spent due to a low number of applications. The drawing of EU funds for the R\&D Operational Programme is low: only 4\% of the funds allocated for the period 2007-13 have been paid out by May 2010 (OECD, 2010f). 
Figure 11. Gross expenditure in R\&D

$\%$ of GDP

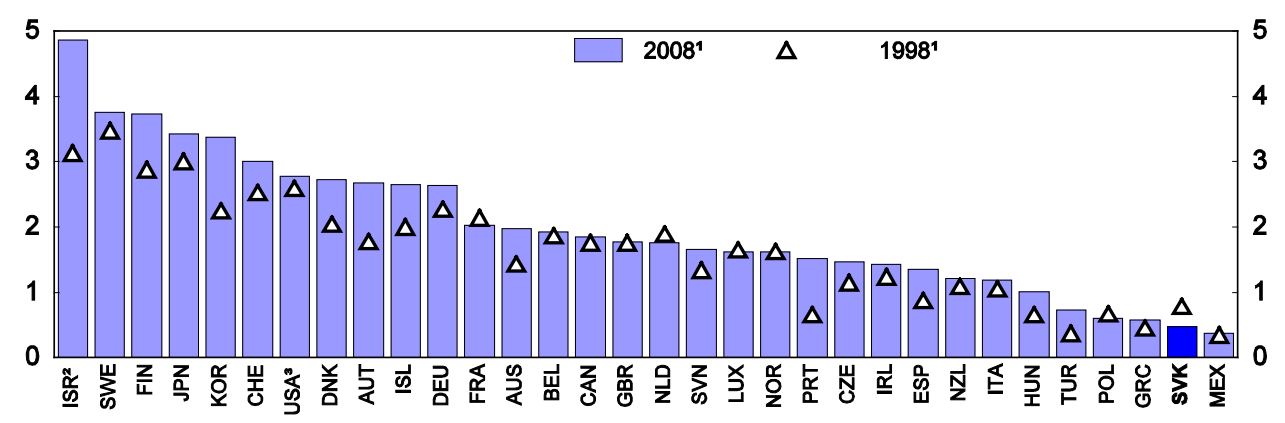

1. Instead of 2008: 2007 for Greece, Mexico and New Zealand, and 2006 for Australia; instead of 1998: 1997 for Greece, Norway, New Zealand and Sweden, and 2000 for Luxembourg and Switzerland.

2. Defence excluded (all or mostly).

3. Excludes most or all capital expenditure.

Source: OECD, Main Science and Technology Indicators Database.

These outcomes may partly reflect the lower income level of Slovakia as the level of R\&D expenditures is closely linked to the level of economic development. However, even compared to countries with a similar GDP level, Slovakia lags behind (Figure 12). The differences in R\&D intensity could be also explained by many other factors, such as differences in the sectoral composition of the economy (Moncada-Paterno-Castello et al., 2010) and specificities in the national institutional framework for innovation activities.

Figure 12. R\&D spending and income levels

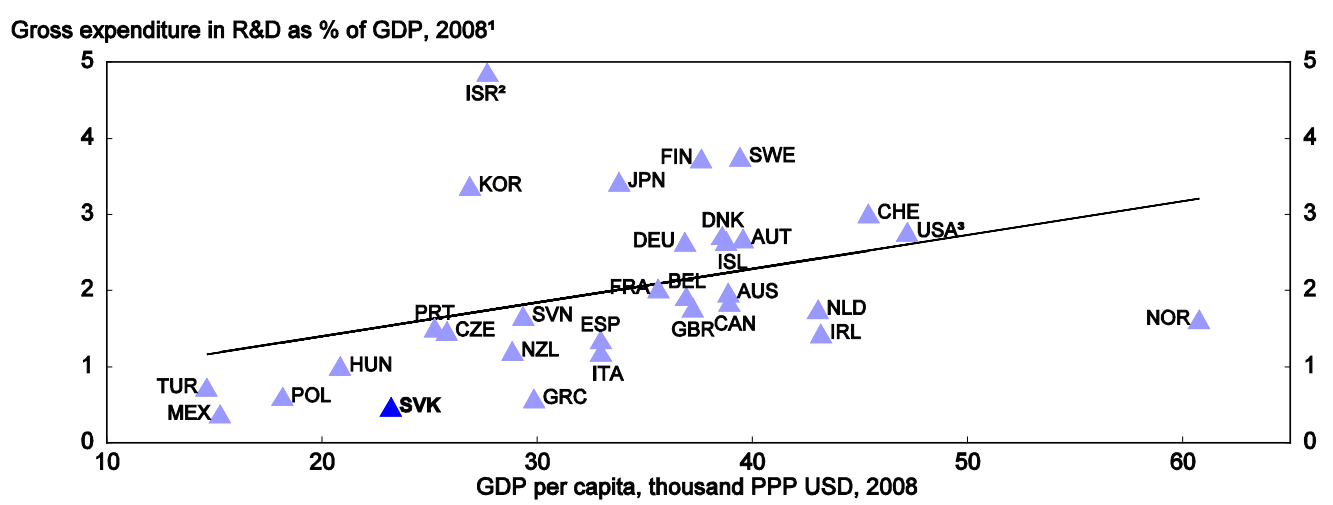

1. Instead of 2008: 2007 for Greece, Mexico and New Zealand, and 2006 for Australia.

2. Defence excluded (all or mostly).

3. Excludes most or all capital expenditure.

Source: OECD, Main Science and Technology Indicators Database and Economic Outlook Database.

The underdeveloped use of policy measures for innovation is a major factor behind the poor innovative performance of Slovakia. Pro-innovative measures appeared after 2000, as innovation became a top priority in "the Competitiveness Strategy for the Slovak Republic until 2010" and in the "Strategy of Innovation Policy of the Slovak Republic for 2008-10" adopted in 2007. Since 2007, many planned 
measures have been postponed, in particular the creation of Regional Innovation Centres, a central project accounting for $45 \%$ of the total amount allocated to the innovation policy for 2008-10. In addition, total R\&D expenditures have been excessively responsive to the business cycle compared to other OECD countries (OECD, 2009b). ${ }^{21}$ This is unfortunate as R\&D is a major determinant of the innovation level and of absorptive capacities of knowledge, i.e. the capacity of firms to select the promising knowledge, to assimilate them, and apply them to commercial purpose (Cohen et al., 1990). When preparing the innovation policy for years 2011-13, Slovakia should thus ensure long-term support to innovation and R\&D by effectively promoting R\&D activities and implementing announced reforms. Regular monitoring and evaluation of innovation policy should be systematic to identify failures of the support system.

The lack of coherence and the complexity of the Slovak innovation policy may also explain this weak innovative performance, in particular because it hampers the public awareness about support for innovative activities. Synergies between innovation policy, managed by the Ministry of Economy and R\&D policy, managed by the Ministry of Education, are missing. Several administrative entities are in charge of the implementation of public support for R\&D without any apparent real cohesion (Box 2). The local needs in public support are not addressed due to a poor co-ordination between the national and regional level. This fragmentation of competencies impedes the creation of a comprehensive functioning innovation system. Slovakia should better co-ordinate innovation policy across government bodies and clearly define competencies in the area of R\&D and innovation. Slovakia should also create a central portal providing information on institutions granting support to innovation and examples of successful innovative strategies.

\section{Box 2. Public support for innovation and business R\&D in Slovakia}

The current public support for private innovation in Slovakia is composed of national grants, R\&D subsidies, mostly in the form of EU-Programmes and tax credits

- The Ministry of Economy, in charge of the innovation policy, provides regional investment aid allocated to investors for the setting up of a new technology centre or the expansion of an existing one (acquisition of material asset and immaterial assets, contribution for newly created jobs).

- $\quad$ Before 2009, the Ministry of Education offered direct public funding of business R\&D via subsidies. Since 1 January 2010, tax incentives have also been introduced in complement. This public funding is distributed to firms creating or developing R\&D activities - basic or applied research, experimental development, elaboration of feasibility studies, protection of intellectual property, and temporary assignment of staff for highly qualified research and development. The level of subsidies decreases with the size of the firm. The system is more generous for basic research $(100 \%$ of the costs are reimbursed) and for projects inducing co-operation with SME and R\&D organisations (universities, research institutes, business organisations of research and development) or cross border co-operation.

- $\quad$ National grants for R\&D projects are allocated by the Slovak Research and Development Agency. The allocation of grants is organised by a system of public call for tenders.

- $\quad$ EU funds allocated to the Operational Programme for R\&D are managed by the Agency of the Ministry of Education of the Slovak Republic for the Structural Funds. The goal of the programme is to modernize and make the system of research and development more effective. The financial support will be used to improve the infrastructure of higher learning schools, support the creation of networks of excellence in research and development and international co-operation, and establish new innovative small and medium-sized enterprises (spin-off activities). EUR 1.4 billion (2.1\% of GDP) has been allocated to this programme. 


\section{Developing efficient financial incentives ...}

The underdevelopment of innovation in Slovakia, a fortiori of eco-innovation, is partly due to the absence of efficient financial incentives for firms to invest in such activities. Implementing environmental policies fosters eco-innovation by creating financial incentives to develop green technologies, processes and products. For example, taxing polluting activities, establishing environmental regulations, launching information campaigns or introducing environmental criteria in public procurement, create demand for green products and so market opportunities for firms. However, market failures may hamper the development of eco-innovative activities and additional public interventions, such as the provision of financial support, is then required (de Serres et al., 2010). The lack of information on the economic impact of pollution and climate change and the credibility of current and future environmental policies make the private returns of eco-innovation investment uncertain. Network, learning by doing and scale effects increase the cost of investments and constitute entry barriers to new technologies. In the energy sector, technologies used depend on existing infrastructure with strong hysteresis effects. In particular, the development of RES requires the expansion of the electricity transmission and distribution network, which is costly and hampers their commercialisation and adoption. Finally, the high risk of not benefiting from their investment may discourage firms from innovative activities.

Slovakia provides financial public support for private R\&D which relies mostly on direct subsidies (Box 2). Developing indirect R\&D supports, such as tax credits, should also be considered as they are likely to increase private $R \& D$ investment, improve the allocation of resources and limit the administrative burden. Empirical analysis suggests that tax credit policies can induce higher private R\&D expenditures than direct government subsidies (OECD, 2003). Tax credits may also be more efficient than public subsidies as they use the commercial expertise from the private sector, which may select the most promising innovations. They avoid "picking winners" and deadweight losses due to asymmetry of information on the market value of innovation. Their main drawback is that they do not orient innovations to environmental issues. In consequence, tax relief would be efficient to foster eco-innovation if complemented by environmental policies which create incentives to innovate in green technologies. As a complement, direct subsidies should be used to develop technologies which are not naturally selected by the private sector because they require long-term research and are too far from commercial viability.

While Slovakia has a tax relief, the application process for it and the non transparency of eligibility rules hamper its efficiency. In the current Slovak funding system, firms have to apply for the tax credit and projects are selected by the administration. This system induces administrative burden and time consuming procedures. Moreover, the financial support is uncertain for firms as it involves prior administrative selection. Clear conditions of eligibility should be defined and projects should only be excluded on eligibility grounds. Application for tax relief should also be simplified and integrated in the procedures for tax collection.

\section{... better protecting property rights}

Strong protection of intellectual property rights (IPR) is also crucial to make eco-innovation profitable. It ensures inventors that their invention will not be used without compensation and guarantees they will get the full returns on their investment. Besides, a strong level of patent protection tends to be positively associated with inward foreign direct investment, international technology transfers and non-resident patenting (Park et al., 2008). The legal framework for IPR protection in Slovakia is comparable to other EU member states. Intellectual property is protected through the implementation of EU intellectual property directives and by ratified international intellectual property protection treaties (e.g. Agreement on Trade-Related Aspects of Intellectual Property Rights, IPR treaties managed by the World Intellectual Property Organization) administered by the Industrial Property Office of the Slovak Republic (IPO). ${ }^{22}$ However, a composite index of patent right protection (Park et al., 2008) ranked 
Slovakia among the ten OECD countries with the least protection of IPR in 2005. The protection rights are restricted as compulsory licensing of certain patents is possible and protection may be lost if the invention is not put to use. In addition, the Slovak IPR system suffers from a weak enforcement (piracy and counterfeiting in particular). ${ }^{23}$ The functioning of the IPR system has improved recently: the procedures have been shortened; the number of pending patents reduced; and the decisions of the Office are now inspected by a court (Industrial Property Office of the Slovak Republic, 2009). This effort should be pursued further and the enforcement of property rights protection should be strengthened.

\section{Improving the business environment by fostering competition ...}

A business-friendly environment is a necessary condition for eco-innovation. In particular, enhancing competition, improving access to capital and increasing the availability of a flexible and skilled labour force are essential to create adequate conditions for firms to innovate and to adapt to a greener economy.

Competition can raise firms' incentives to innovate and improve their cost-efficiency. Firms on contestable markets are encouraged to exploit new technologies to gain market share and most radical innovations are performed by new firms (de Serres et al., 2010). Thus, removing entry barriers in product markets is beneficial for innovation. ${ }^{24}$ In addition, flexible product market regulation (PMR) could support the reallocation of firms during structural changes. Slovakia's regulatory policy environment is more restrictive than that of the other Visegrad countries (Figure 13). It scores relatively poorly in PMR indicators for barriers to entrepreneurship, in particular for the regulatory and administrative opacity and the administrative burdens on start-ups indicators. This picture is confirmed by the Doing Business survey of the World Bank: even if Slovakia has made some notable progress in facilitating the start up of new businesses, starting a new business is still more complicated, costly and time-consuming than in many other OECD countries (World Bank, 2010). In consequence, Slovakia should identify administrative burdens, as planned in the Modernization Programme Slovakia 21, and quickly establish a timetable for measures aimed at tackling the identified business barriers. Administrative procedures should be simplified, by establishing single contact points for firms and unifying procedures for the collection of social security contributions (OECD, 2010f). ${ }^{25}$ 
Figure 13. Restrictive product market regulations

Index scale of 0-6 from least to most restrictive
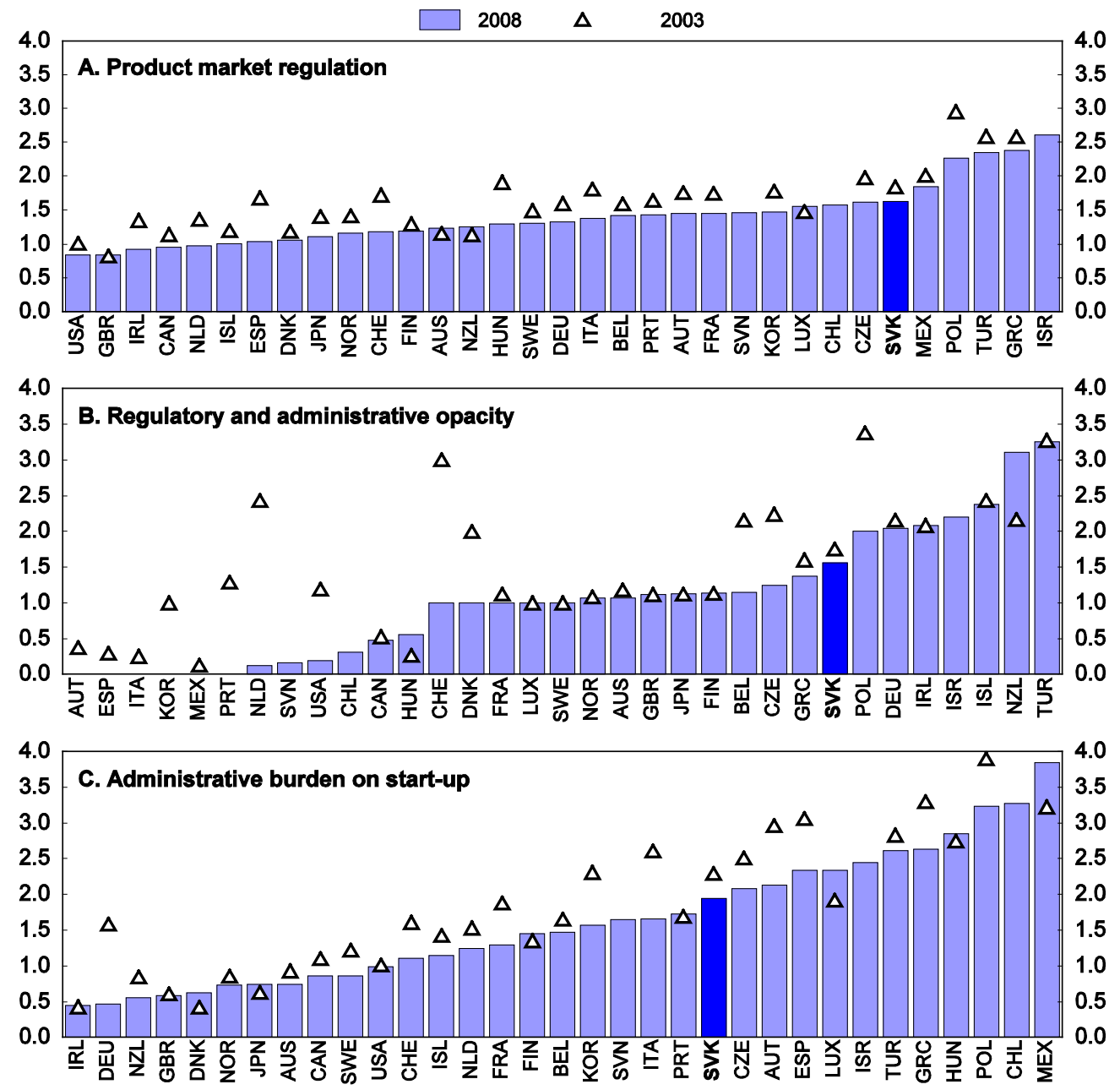

Source: OECD, Indicators of Economy-wide Regulation (PMR), www.oecd.org/eco/pmr.

In Slovakia, network industries and services are characterized by important regulatory barriers. Product market competition should be strengthened in these sectors (OECD, 2007). Specific attention should be given to the energy sectors where competition is underdeveloped despite the recent opening up of the markets and where potential gains of eco-innovation are important (Box 3). Regulation of energy prices could deter the development of competition as it sends a bad signal to potential competitors and may be too restrictive to make investment in the energy market profitable. When determining regulated prices, the Regulatory Office for Network Industries (RONI) has to ensure that the regulation does not hamper the entry of new competitors. In particular, the price-setting framework should be more stable and transparent. Besides, prices should not be lowered for social reasons. First, by artificially reducing energy prices, it lowers the profitability of entering the market for new investors. Second, it is not efficient because not targeted on low income households. Third, it has adverse environmental effects as it discourages households to reduce their energy consumption and invest in energy efficient equipments. Targeted measures could be implemented to compensate low income households for increases in energy prices. The low level of competition may be also due to non-price discrimination of new entrants. Unambiguous and transparent rules for the access conditions to the grid, the enforcement of contracts and the authorization 
procedures for the construction of new power plants should be set to avoid the exclusion of potential competitors.

\section{Box 3. Competition and innovation in the energy market}

Innovation in the energy market is crucial to address environmental challenges and increase energy efficiency in particular. Low competition is a barrier to development of innovation in this sector (de Serres et al., 2010). Incumbent companies are not encouraged to adopt energy-efficient technologies and to increase their productivity as they do not fear losing market share and not surviving the entry of new competitors.

In line with EU legislation, the Slovak energy market is being progressively liberalized. Many regulatory barriers to entry have been removed with the opening of the energy market in 2005 for non-household customers and in 2007 for households. Legal unbundling and partial privatization in the electricity and the gas sector was progressively completed. On the electricity market, the number of licenses issued by the Regulatory Office for Network Industries (RONI) has increased over the past few years (from 112 in 2005 to 335 in 2009) and four new companies entered the market for electricity provision to industry recently. However, competition has not developed strongly; the incumbent companies are still dominant, notably for energy production and energy provision to households.

The low level of competition could be partly explained by the regulatory framework which creates entry barriers to new entrants:

- $\quad$ Prices in network industries (electricity, gas, water supply, sewage collection, and other selected businesses) are regulated by RONI. The regulation is implemented in activities where competition is not developed to better reflect production costs and to prevent excessive increases in energy prices due to a low competition level. An incentive based regulatory method is used for regulation to create conditions for more competition. The RONI determines price caps for three years ahead based on the assessment of operating costs of the operators and inflation. This system is supposed to encourage firms to reduce their production costs below the price cap to increase their profit margin. However, the price setting lacks transparency and stability which may hamper long term investment in the energy sector and thus the development of competition, in particular for energy provision to households. For electricity, the prices for the connection to the grid, the connection of the new producers to the system, the system and support services, the access to the transmission and the distribution system, and the supply to the households are regulated. Managing network access prices to reasonable levels benefits competition by limiting fixed costs for the new entrants. The prices for distribution could be lowered further by using cost benchmarks, taking into account costs in neighbouring countries, in addition to price-caps. On the contrary, the price cap for energy supply for households could deter the entry of new providers and have negative environmental effects, because price signals to reduce demand are suppressed.

- The low competition level could also be explained by non-price discrimination of competitors by distribution network owners. Strengthening the regulatory framework would ensure and control transparency and non-discriminatory behaviour (OECD, 2005). The access conditions to the grid should be made easily available to potential market entrants (access prices and available capacity on network and international connections). Unambiguous and transparent rules to the enforcement of contracts e.g. on conditions to cancelation of contracts, on the allocation of connection costs between network operators and market entrants should be set ex ante by the regulator. Authorization procedures for the construction of new power plants should be streamlined. Care should be taken to avoid cross-ownership between companies operating on the energy market.

The protection of investors against uncertainty regarding the legal framework is also a crucial determinant of long term investment and thus innovation. The Doing Business Survey suggests that protection of investors could be reinforced in Slovakia. The delays to enforce a contract are significantly above the average (565 days vs. 462 in the OECD) and the recovery rate after bankruptcy is low (only $46 \%$ of the investment cost is recovered from the insolvent firm vs. $69 \%$ in the OECD). In addition, Slovakia 
continues to rank poorly in the Transparency International's corruption perception index, which may add to the uncertainty for investors. Public sector accountability should then be improved; in particular, the management capacity and accountability of the judicial sector needs to be strengthened. Sustained anti-corruption efforts are required and the power of oversight institutions should be reinforced.

\section{... ensuring access to capital}

The lack of funds is another main factor hampering innovation in Slovakia, especially for SMEs. In general, the uncertainty about the expected gains from innovation activities limits the access to credit and to financial markets. In Slovakia, the supply of finance for innovative activities, especially for businesses in the early phase of their development, is particularly underdeveloped. Banks require strict collateral and a high risk premium. Venture capital supply is weak. In 2003, the level of venture capital as a share of GDP was the lowest in the OECD. In 2008, according to the European Venture Capital Association, it reached $0.05 \%$ of GDP, about one tenth of the European average ( $0.4 \%$ of GDP) and is also below the average of Central and Eastern Europe ( $0.2 \%$ of GDP). This may partly be explained by the fact that pension funds and insurance companies are not allowed to invest in private equity and venture capital.

Slovakia participates in the Joint European Resources for Micro to Medium Enterprises (JEREMIE) initiative, a European programme to improve access to finance for SMEs in the less developed regions of the EU. The project consists of providing guarantees for loans and venture capital finance to SMEs. It is intended to increase the volume of credit available to SMEs, but also, as the funds are allocated by financial intermediaries, to encourage these intermediaries to develop their SME lending capacity. The government plans to support highly innovative firms by providing "risk capital" as returnable financial aid. These initiatives to develop the venture capital market should be pursued further.

\section{... improving labour mobility and skills availability}

Adapting to a greener economy benefits from a flexible labour market, able to adjust to structural change. The transition to a greener economy will entail modifications of the sectoral composition of the economy which should be accompanied by the reallocation of workforce and the adaptation of available skills. Workers will have to switch to a new type of job and firms need to find an appropriate workforce. To address this challenge, Slovakia should improve the adaptive capacity of its labour market which is characterized by a high share of long-term unemployed in total unemployment, specifically in certain regions, and a job mobility level among the lowest in the OECD (OECD, 2010e) ${ }^{26}$ Strict employment protection legislation may reduce the job reallocation in hampering the prices and wages adjustments and may also impede the voluntary job mobility of employees across sectors and occupations (OECD, 2010e). Low geographical labour mobility is also a barrier to job reallocation, in particular when the sectoral changes are located in specific regions. One of the obstacles to greater mobility is the lack of an appropriate rental housing market and the set-up of the housing allowance system which is limited to recipients of social assistance (and excludes workers) and does not take regional variations in housing costs into account (OECD, 2009c). Adjusting housing policy, in particular by removing obstacles to the expansion of a private rental market, and ensuring that job protection legislation is not excessive would improve job mobility.

Training and lifelong learning will play a crucial role in the adaptation of workers' skills to the needs created by these structural changes. Labour shortages may rise with the development of new green technologies and the structural changes related to climate mitigation policies. Training accounts for a small share of the active labour market programmes (4\% of total ALMP spending) and participation in non-formal job related education and training is relatively low by international comparison. ${ }^{27}$ Training and life-long learning should be developed to avoid skills gaps in the labour market and better tailor to market needs. In this respect, a good functioning of the training market should be guaranteed, for instance by 
providing information on the quality and returns of the training and ensuring recognition of learning outcomes in the labour market and in the educational system. The efficiency of lifelong learning policies could also be improved by involving social partners in their design and implementation (OECD, 2006). Slovakia is implementing measures in this direction. In 2009, a law on lifelong learning created the framework for the accreditation and the assessment of training programmes. To better assess and anticipate the labour market needs in formal and non-formal learning and to ease the recognition of competencies, Slovakia is establishing a National System of Occupations, which provides a description of occupations and the related qualification requirements in co-operation with the private sector. For this occasion, special attention should be given to "green skills" (i.e. ability to use green technologies and techniques) which should be included in the educational programmes.

\section{Developing a knowledge economy by increasing human capital}

To seize the opportunities to exploit cleaner sources of growth and develop new green industries, jobs, and technologies, Slovakia has to encourage the development of a knowledge-based society. The innovative and absorptive capacity of the economy - i.e. the capacity to understand, assimilate and apply innovation - significantly relies on the quality of human capital formation, on the availability of researchers and of high skilled workers, on the efficiency of knowledge transfers and on the development of Information and Communication Technologies (ICT).

Level and quality of human capital formation is an important determinant for the innovative capacity of a country as it influences the potential for creation and diffusion of knowledge. In Slovakia, the level of human capital accumulation seems to be very weak (OECD, 2007). In particular, the level of tertiary educational attainment is low. In 2008, only $15 \%$ of the Slovak population had a tertiary education level (vs. 28\% in the OECD on average). The wage premia earned by tertiary graduates compared to secondary graduates is high compared to other countries (Figure 14). This may partly reflect the low availability of tertiary educated workers in Slovakia. In 2009, 50\% of employees in high-skilled occupations did not hold a university degree (OECD, 2010b). In addition, emigration seems quite high for the educated population in Slovakia. According to LFS data, no less than 7\% of the labour force was abroad in 2008. Studies on brain drain found that a significant part of the educated population leaves the country to work abroad: in $2000,16 \%$ of Slovak residents with tertiary attainment emigrated (Divinský, 2007). Some labour shortages due to high emigration rate are also observed in the health sector (OECD, 2010f).

Figure 14. Relative earnings by level of education

2008 or latest available ${ }^{1}$

Upper secondary and post-secondary non-tertiary education (ISCED 3/4) $=100$

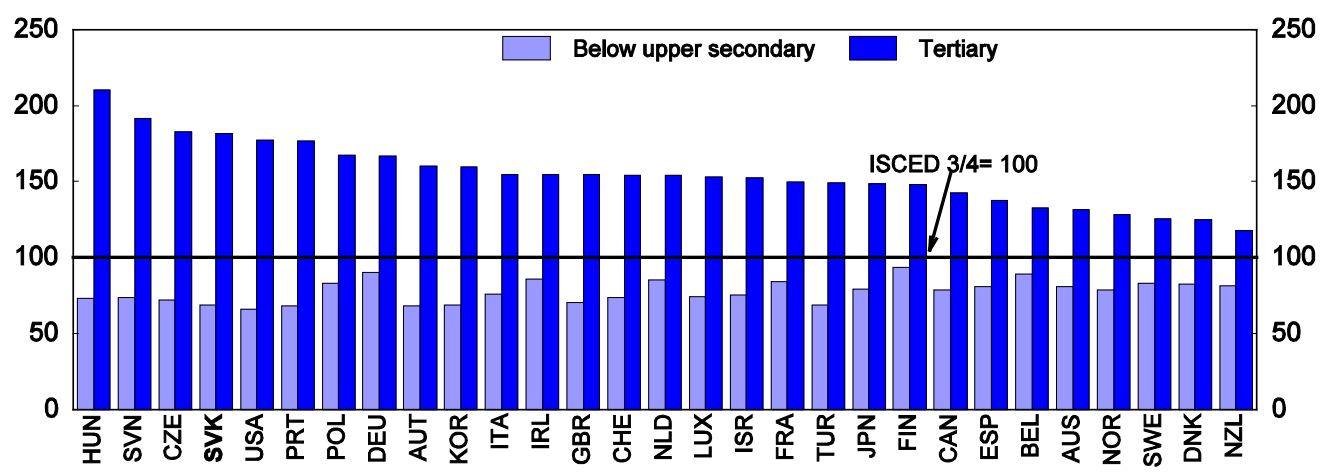

1. 2007 for Canada, Finland, France, Japan, Korea, Norway, Slovenia and Spain; 2006 for Italy, Luxembourg, the Netherlands and Portugal; 2005 for Austria, Belgium, Ireland and Turkey.

Source: OECD, Education at a Glance 2010 (Table A7.1). 
The situation is getting better, as the number of tertiary students and graduates has increased sharply over the past few years, but a few indicators point out that the quality of the Slovak tertiary educational system should be further improved. Slovakia is below the EU27 average in terms of citation in academic reviews (ISI/Thomson Reuters citation index) and no Slovak universities appear in the Academic Ranking of World Universities. Besides, the Slovak higher education institutions are not internationally attractive: international students represent only $0.9 \%$ of the all tertiary enrolments in 2007 (below the 7.1\% OECD average) and the share of foreign doctoral students is among the lowest in the OECD (Figure 15). Allowing state institutions to introduce tuition fees for full-time students, coupled with income contingent repayments, could help to increase the quality of tertiary education by increasing students' demand for quality improvements. The outcomes of the tertiary education system could also be improved by encouraging competition in the tertiary education. The entry of new institutions - including foreign institutions - should be facilitated by upgrading the licensing requirements. Finally, budgetary allocations to universities should be replaced with competitive research grants or at least rely more on educational outcomes as planned by the government.

Figure 15. Share of foreign tertiary students

2007 or latest available, ${ }^{1} \%$ of all tertiary students in host country

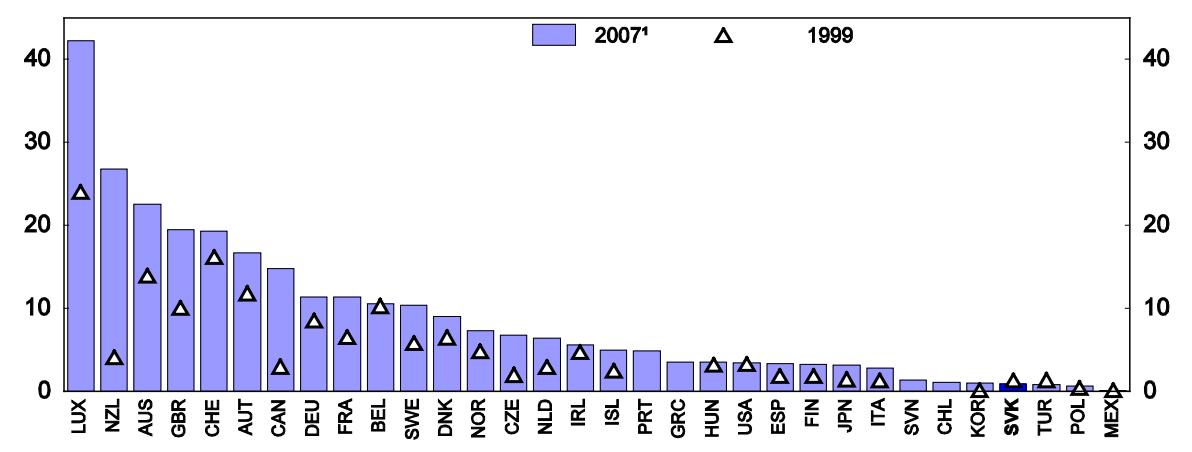

1. 2006 for Luxembourg, 2004 for the United States, 2003 for Ireland and 2002 for Mexico. Source: OECD, Online Education Database (www.oecd.org/education/database).

The number of researchers, closely linked with the level of innovative activity, is very low in Slovakia not least because the Slovak labour market is not attractive for these high-skilled workers. Less than 1 researcher per 1000 employees works in industry and the total number of researchers per thousand of total employment was only 6 in 2008. This can be explained by the underdevelopment of innovative activities and thus by the low attractiveness of research positions: after five years of activity, $60 \%$ of doctorate holders in Slovakia remain under temporary contracts (OECD, 2009b). Also, doctorates holders are significantly better paid when they do not work as researchers (OECD, 2010b). Slovakia may not be attractive for foreign researchers because important barriers limit the immigration opportunities in this country. ${ }^{28}$ No migration policy to attract high-skilled migrants is defined. A new Immigration and Naturalization Office (INO) which would centralize the responsibility for migration issues might be created in 2010. The creation of the INO and the transposition of the EU Directive on the admission of highly skilled immigrants are good opportunities to revise the migration policy in particular towards high-skilled workers. For this occasion, the government should consider removing the barriers to human capital flows and facilitating high-skilled migration.

\section{... developing knowledge transfers}

A lack of information on research and of collaboration between the public and the private sectors in R\&D activity may induce low innovation performance. Weak ties between industry and the academic sector hamper the use of basic research in the business sphere and disconnect academic research from market needs. Several indicators show that these ties should be reinforced in Slovakia. A low mobility of 
science and research workers between the public sector and industry and a small share of collaborating firms are observed (SME in particular) (Figure 16). The development of exchanges between the business sector and the academic sphere is one of the main objectives of the Slovak Innovation Policy. $45 \%$ of the budget of the Innovation Policy was allocated to the construction of regional innovation centres designed to foster information exchanges. The government should intensify support for co-operations by universities, research institutes and enterprises and encourage mobility of researchers between public and private institutions. The development of academic entrepreneurship that is based on technology developed within university laboratories should also be fostered by explicitly recognizing them as funding relevant output.

Figure 16. Firms collaborating on innovation activities by size

$2004-06^{1}, \%$ of all firms

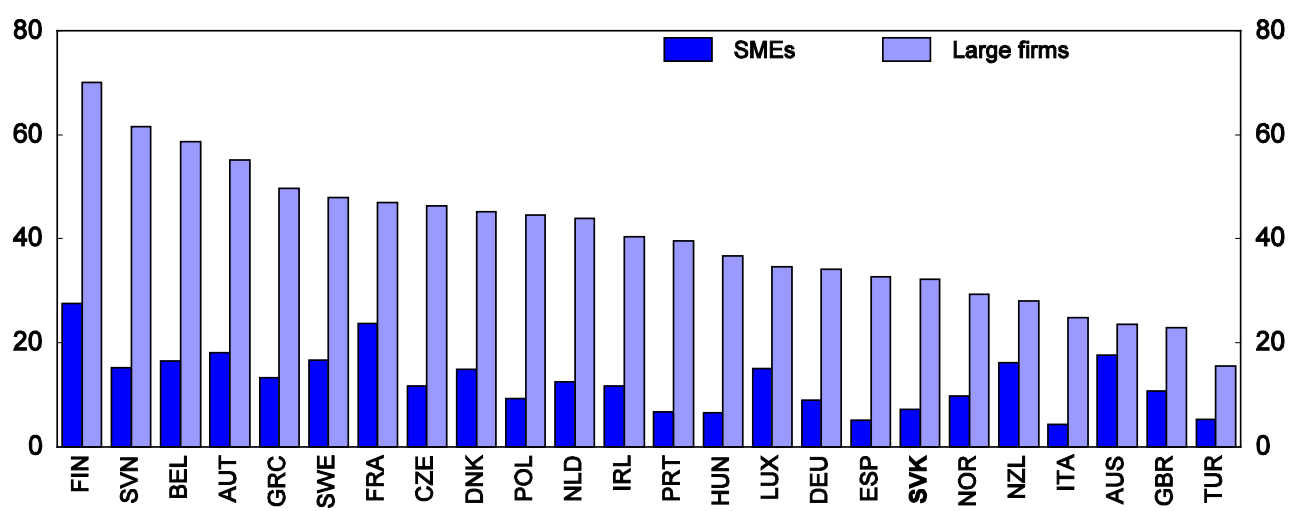

1. 2006-07 for Australia and New Zealand.

Source: OECD, Science, Technology and Industry Scoreboard 2009.

Exchanges between firms foster the diffusion of know-how and create positive spillover effects. These links are difficult to develop because in sharing their knowledge firms could lose the benefit of their investments. The dilemma between technological diffusion and incentives to innovate could be addressed by developing knowledge markets and knowledge networks, encouraging cross-financed projects and fostering the use of patent pools.

International co-operation should also be encouraged, as it broadens knowledge inflows and allows sharing the cost of innovation development. The foreign collaboration in R\&D is highly developed in Slovakia: $16 \%$ of business R\&D spending is funded from abroad (OECD, 2009b) and more than 20\% of firms are collaborating on innovation with foreign partners across Europe (Figure 17). Foreign direct investment (FDI) has been a channel of innovation diffusion and has contributed to technological transfer. Slovakia also benefits from foreign R\&D centres collaborating with the domestic R\&D organisations and universities. A national agency, the SARIO (Slovak Investment and Trade Development Agency) is in charge of developing the attractiveness of Slovakia as an R\&D location. The agency provides information to foreign investors on the opportunities for R\&D in Slovakia. To increase the potential contribution of foreign firms to eco-innovation, regulatory barriers to international exchanges such as discriminatory procedures towards foreign firms, should be removed. In particular, foreign firms should be allowed to have redress through regulatory authorities and regulations should be published in a manner accessible at the international level. More generally, the ties between domestic and FDI firms should be strengthened (for instance by fostering intermediate domestic supply) to ease knowledge diffusion and technological spill-overs, and to improve Slovakia's attractiveness for foreign investors. In addition, participation of 
Slovak R\&D organisations in cross-border programmes such as European Union and interregional programmes remains weak and should be encouraged.

Figure 17. Firms collaborating with foreign partners on innovation within Europe

2004-06, \% of all firms

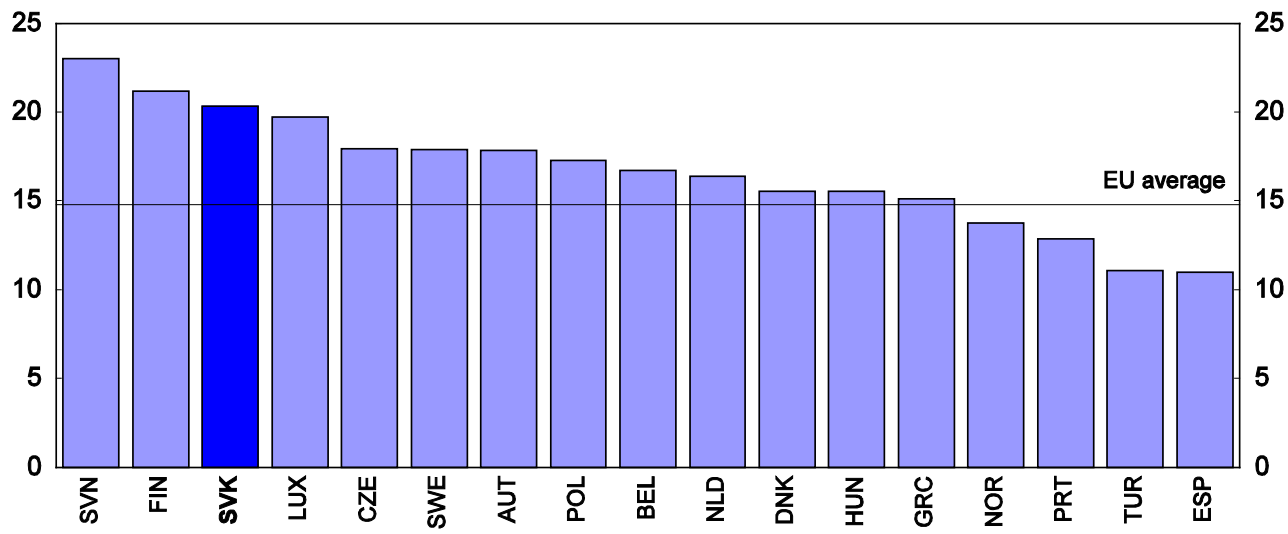

Source: OECD, Science, Technology and Industry Scoreboard 2009.

\section{... and investing in ICT}

Information and communication technologies (ICT) have the potential to increase innovation by speeding up the diffusion of information, improving the transfer of knowledge and technologies favouring networking among firms, reducing geographic limitations and increasing efficiency in communication. ICT may also increase productivity as it enables firms to restructure their organisations and to develop new products and processes (OECD, 2004). Empirically, ICT use tends to raise the probability to innovate both in manufacturing and in services sectors (OECD, 2010b). ICT have also a specific impact on eco-innovation, as ICT systems enable an increase in energy efficiency of production and consumption, by product improvement (energy-efficient vehicle) or by creating entire systems to control energy consumption (smart electricity grids, transport management) (OECD, 2009d). For example, the losses of electricity during transmission could be lowered by the development of smart grids. ICT also influence consumption habits by facilitating the diffusion of information on the environmental impact of economic activities and polluting/green products. They can also have a direct impact on the environment (equipment production, use, end of life treatment) which should be considered when implementing their development.

Despite substantial progress over the past few years, access and use of ICT, broadband networks in particular, need to be developed further in Slovakia. Broadband penetration has increased sharply, but is still the fourth lowest in the OECD (Figure 18). The speed of the Slovak DSL extension is also relatively low compared to other catching up countries and its development is quite unequal across the regions. Between 2005 and 2006, the DSL subscriptions increased less than 20\% in Slovakia, while they increase at over 60\% in Czech Republic and Hungary. To promote greater broadband deployment and develop access to broadband infrastructure, Slovakia intends to better target the public funding on isolated areas not served by private operators. Slovakia should pursue its investment in network and ICT skills development without pre-empting private initiatives. Public intervention on these sectors should be assessed regularly to determine their efficiency and necessity. However, investing in ICT infrastructures will not be sufficient to ensure an efficient use of these technologies. A supportive environment for the development and growth of the IT sector still needs to be created. In particular, competition on the telecommunication sector should be ensured and ICT skill formation should be developed (OECD, 2005). 
Figure 18. OECD fixed broadband subscribers per 100 inhabitants, by technology December 2009

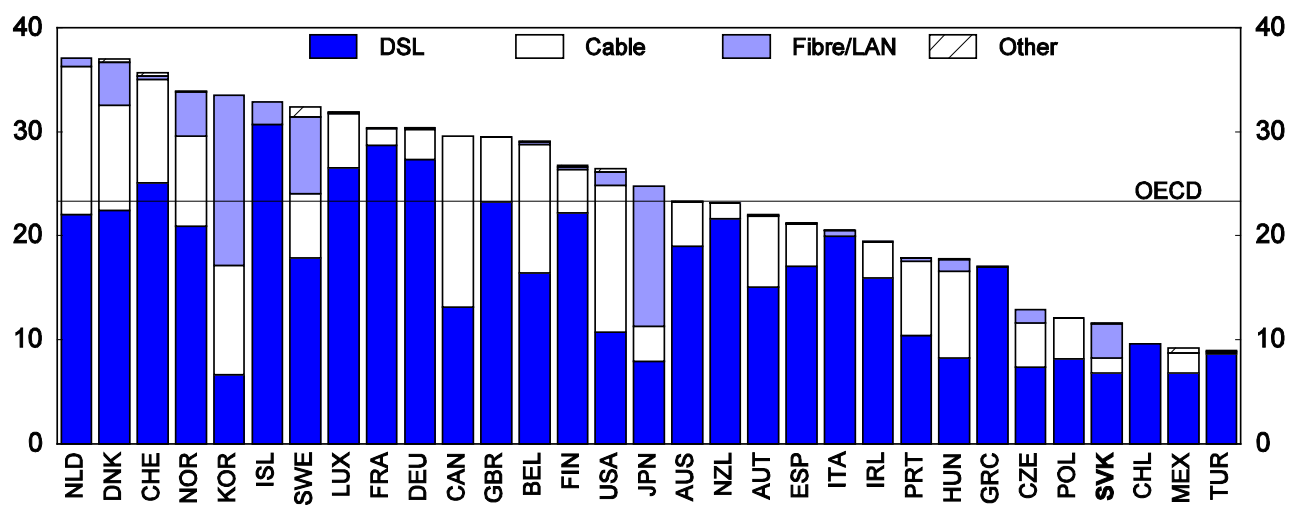

Note: The data presented in the chart below do not include fixed wireless subscriptions.

Source: OECD, Broadband Statistics, December 2009 (wwww.oecd.org/sti/ict//broadband). 


\section{Box 4. Recommendations for a transition to greener growth}

Addressing the challenges and making economic growth more environmentally sustainable

Pricing pollution by extending environmental taxation and removing harmful exemptions and subsidies

- $\quad$ Phase out the tax exemptions on energy and pursue their social goals by other economic instruments, such as financial compensation targeted on low income households.

- $\quad$ Extend environmental taxation; establish a clear, predictable and credible carbon tax in the sectors not covered by the EU ETS and reform taxation of motor vehicles by setting rates depending on emissions and energy consumption.

Improving the framework of environmental policy and selecting the most efficient tools to foster environmental-friendly activities

- $\quad$ Strengthen co-ordination among administrative bodies by reforming the framework of environmental and energy policies. Centralize the determination, the implementation and the monitoring of these policies, while merging instruments and funds addressing the same issue.

- Better target the support to environmental-friendly activities by defining measurable targets and systematically carrying out evaluations. In particular, monitor the cost effectiveness of measures aiming at developing RES (feed-in tariffs).

- Review regulatory barriers to the renewable energy sources (RES) development in the solar and wind energy sector. Clarify the rules behind the allocation of certificates for solar plants. Reassess environmental rules limiting the installation of windmills by using international benchmarking.

- $\quad$ Phase out subsidies which can be replaced by other market-based instruments. For instance, remove tax exemptions on electricity produced from RES. Review the features of subsidies aimed at addressing specific market externalities. Replace subsidies for RES equipments by soft loans and complement them with an information campaign on the gains related to RES production or at least better target subsidies on credit-constrained households.

\section{Creating a framework for eco-innovation}

- Ensure a long term support to innovation and R\&D by effectively increasing the weight of R\&D in public expenditures, by better co-ordinating innovation policy across government bodies and by evaluating innovation policy regularly.

\section{Developing efficient financial incentives and better protecting property rights}

- $\quad$ Consider developing R\&D activity by complementing the current financial support with tax credits and limit direct public subsidies to basic research or research far from commercial viability. Simplify application procedures for public funding and create clear conditions of eligibility for tax credits to avoid discretionary selection of projects.

- Strengthen the enforcement of property rights protection.

Improving the business environment

- Identify administrative burdens and establish a timetable for measures aimed at tackling the identified business barriers. Develop further the establishment of single contact points for firms and unifying procedures for the collection of social security contributions.

- Strengthen competition in network industries, notably in the energy market. Ensure that the price 
regulation does not deter the entry of new competitors, notably by improving the stability and the transparency of the price setting framework and reduce non-price discrimination.

- $\quad$ Ensure access to capital by pursuing initiatives to develop a venture capital market.

- Improve skilled labour force availability by removing obstacles to labour mobility such as barriers to the expansion of a private rental housing market, by developing lifelong learning, by ensuring the good functioning of the training market and by including training in "green skills" (i.e. ability to use green technologies and techniques) in the educational programmes.

\section{Developing a knowledge economy}

- Improve the quality of tertiary education by introducing tuition fees for full-time students at state universities coupled with income contingent repayments, facilitating entry of new institutions, replacing budgetary allocations to universities with competitive research grants or at least making them rely more on outcomes.

- $\quad$ Remove barriers to labour flows at the national (e.g. between the academic and the business sphere) and international level. Facilitate high skilled migration.

- Intensify support for international co-operation, participation in cross-border programs, and crossfunding of projects, develop knowledge networks and encourage collaboration between universities, research institutes and enterprises.

- $\quad$ Pursue public investment in ICT infrastructures without pre-empting private initiatives and regularly reassess the efficiency and the necessity of these interventions.

- Develop competition in the telecommunication sector.

\section{Notes}

1. Emissions decreased in the energy sector (public electricity and heat generation in particular), agriculture, manufacturing industries (decrease in energy use) and services, but increased in transport, waste and industrial processes.

2. Energy intensity is measured as the ratio of total final energy consumption in Mtoe and GDP in 2000 USD PPP.

3. For instance, the national policy on air pollution, implemented since 1991, includes charges for basic air pollutants (NOx, SOx). The EU Directive 2008/1/EC on the Integrated Pollution Prevention and Control requires new industrial installations covered by the Directive (as middle and large scale energy units) to get an environmental permit and to use the Best Available Techniques (BAT).

4. The OECD data on $\mathrm{CO}_{2}$ emissions from fuel combustion for 2007 confirm this finding $(0.41 \mathrm{~kg} \mathrm{CO} / \mathrm{GDP}$ in 2000 USD PPP vs. 0.32 for the EU27 average).

5. This is partly because the less-costly options for the abatement, such as the replacement of old polluting technologies have already been exploited. 
6. This result could be also partly due to a higher relative price of energy in Slovakia due to the Balassa-Samuelson effect.

7. Electricity and heat produced with oil and coal are more carbon intensive than gas and nuclear power. On average in the OECD, electricity and heat produced with coal create $903 \mathrm{~g}$ of $\mathrm{CO}_{2}$ per $\mathrm{kWh}, 599 \mathrm{~g}$ for oil and $377 \mathrm{~g}$ for gas (Source: OECD, Emissions per $\mathrm{kWh}$ of Electricity and Heat Output, edition 2009).

8. $\quad$ Electricity and heat production is ensured by Combined Heat and Power (CHP) plants and heat plants whose returns are generally higher than for electricity plants and whose yields are slightly better than in many other OECD countries.

9. Climate change may result in potential damages such as a rise in sea level, a reduced availability of resources and development of infectious diseases with a global negative impact on human wealth. The desirability of keeping the rise in global temperature below 2 degrees Celsius by reducing GHG emissions was recognised during the UN Copenhagen conference on climate change mitigation.

10. As an illustration, the negative macroeconomic effect of oil price shocks has been weaker in the 2000s than in the 1970s partly due to a decrease in oil intensity (Blanchard et al., 2007). An increase in oil prices resulting in a general increase in energy prices has a significant impact on potential output (Cournède, 2010): an increase of oil prices from USD 50 to USD 80 is estimated to decrease real potential GDP by $0.7 \%$ in the euro area.

11. This figure is provisional and should be interpreted with caution. The Ministry of Environment, the Ministry of Finance and the Statistical Office are elaborating a comprehensive classification of environmental taxes and charges and are updating the data used in the OECD/EEA database.

12. Electricity, oil and gas prices are above the OECD average but coal price for households is significantly lower.

13. The government established the national energy efficiency target in line with the EU commitment: the EU Directive 2006/32/EC stipulates energy savings of $1 \%$ per year compared to the previous five-year average energy consumption. The intermediate national energy savings target until 2010 is set as energy savings of 3\% as compared to average final energy consumption in the period 2001-05 and the long-term national energy efficiency target until 2016 is set as energy savings of 9\% compared to the same reference level.

14. In the housing sector, the projects could potentially be financed by national funds such as SLOVSEFF, the State housing development fund (SFRB), the Programme for support of housing development, the subsidy system for elimination of systemic failures, and the EU funds through notably the Regional Operational Programme (2007-13) "Improving the thermal properties of building use for civil infrastructure”. The same applies to RES with the Environmental Fund, the Programme for Promotion of Biomass and Solar Energy Use in Households, and three different EU funds (Operational programmes (OP) for Competitiveness and Economic Growth, OP Environment or Rural development programme).

15. Existing subsidies for RES electricity in some countries exceed EUR 250 per ton of $\mathrm{CO}_{2}$ abated for wind power and EUR 1000 for photovoltaic equipments (Lawson, 2010), well above the price of carbon emission in the EU ETS (between EUR 15 and EUR 30 per $\mathrm{CO}_{2}$ ton).

16. No supply shortages and no increase in RES equipment prices have been observed in Slovakia after the setting up of the programme promoting the use of RES, probably because this policy has been launched during the economic crisis and was only slightly successful.

17. The impact on electricity prices was estimated by the Ministry of Finance at $10-12 \%$.

18. The existing technologies are not relevant for all economic activities. For example, solar and wind are only appropriate for electricity generation (Lawson, 2010). 
19. The OECD definition of eco-innovation is based on the Oslo Manual and drawing from other sources (OECD, 2010d).

20. Technology balance of payments measures international technology transfers (e.g. licence fees, patents, purchases and royalties paid, know-how, research and technical assistance, industrial R\&D). The available data show that the bulk (over 60\%) of such technology transfers in the majority of countries are between parent companies and affiliates, which reflects the central role of direct investment in the technology balance of payments. More details are available in OECD (2005), Measuring Globalisation: OECD Handbook on Economic Globalisation Indicators, OECD, Paris

21. The business financed R\&D is more countercyclical than the total spending (the elasticity of the business $R \& D$ to the total spending is over 1), as in the majority of OECD countries (OECD, 2009b).

22. The IPO is a central state administration body responsible for the IPR protection and administration of international treaties. It provides public documentation and information on patent and trademark and carries out pre-diagnostic of industrial rights.

23. This finding is confirmed by the Executive Opinion Survey of the World Economic Forum which indicates that business executives do not perceive the IPR protection as strong in Slovakia (World Economic Forum, 2009).

24. Empirically, competition is positively linked with the level of investment (Alesina et al., 2005), efficiency gains (Nickell et al., 1997; Nicoletti and Scarpetta, 2003), and innovation performance (Aghion et al., 2005; Griffith et al., 2006).

25. Single contact points enable entrepreneurs to perform all administrative acts necessary to start and carry out a business at one single point, and could lower the weight of procedures and cost of obtaining permits to businesses.

26. In particular, job to job mobility of human resources in science and technologies is small: in 2007, less than $4 \%$ of employees changed jobs from one year to the next (OECD, 2010b).

27. In 2009, only 33\% of firms offer formal training to their employees against $42 \%$ on average in the OECD (World Bank Enterprise Surveys).

28. A lot of procedures have to be achieved to get the right to work in Slovakia as non-EU national. The migrants must hold a work permit delivered by the Labour, Social Affairs and Family office and a residence permit delivered by the Slovak Foreign Police. Recent changes in the legislation ease the conditions of entry for intra-corporate transferees, investors and students somewhat (amendments to the Aliens Act on 1 January 2010), but they remain constraining. 


\section{Bibliography}

Aghion, P. et al. (2005), “Competition and Innovation: An Inverted-U Relationship”, Quarterly Journal of Economics, Vol. 120:2, Oxford.

Aghion, P., D. Hemous and R. Veugelers (2009) “No Green Growth without Innovation”, Bruegel Policy Brief Issue, 2009/07.

Alesina, A. et al. (2005), "Regulation and Investment”, Journal of the European Economic Association, Vol. 3, No. 4, pp. 791-825.

Blanchard, O.J. and J. Gali (2007), “The Macroeconomic Effects of Oil Price Shocks: Why are the 2000s so Different from the 1970s?” MIT Department of Economics Working Papers, No. 07-21.

Cazalda, G.A. et al. (2009), "Study of the effects on employment of public aid to renewable energy sources”, Universidad Rey Juan Carlos, Madrid, www.juandemariana.org/pdf/090327employment-public-aid-renewable.pdf.

Cincera, M., D. Czarnitzki and S. Thorwarth (2009), "Efficiency of public spending in support of R\&D activities”, European Commission, Brussels.

Cohen, W. and D. Levinthal (1990), "Absorptive capacity: A new perspective on learning and innovation”, Administrative Science Quarterly, Vol. 35, Issue 1, pp. 128-152.

Cournède, B. (2010), “Gauging the impact of higher capital and oil costs on potential output”, Economics Department Working Papers, No. 786, OECD, Paris.

Divinský, B. (2007), "Labor market - migration nexus in Slovakia: time to act in a comprehensive way”, International Organization for Migration, Geneva.

European Central Bank (ECB) (2010), "Energy Markets and the Euro Area Macroeconomy”, Structural Issues Report, ECB, Frankfurt/Main.

European Environment Agency (EEA) (2009), “Greenhouse gas emission trends and projections in Europe 2009: tracking progress towards Kyoto targets”, EEA Reports, No. 9/2009, EEA, Copenhagen.

Geller, H. and S. Attali (2005), "The experience with energy efficiency policies and programmes in IEA countries”, IEA Information Papers, IEA, Paris.

Griffith, R., R. Harrison and H. Simpson (2006), “The Link Between Product Market Reform, Innovation and EU Macroeconomic Performance”, European Economy Economic Papers, No. 243.

IEA (2008), IEA Energy Policies Review, the European Union, IEA/OECD, Paris. 
IEA (2009), Energy Balances of OECD Countries, IEA/OECD, Paris.

IEA (2010), Energy Prices and Taxes, 1st Quarter, IEA/OECD, Paris.

Industrial Property Office of the Slovak Republic (2009), The unique deserves protection - Annual Report 2009, Industrial Property Office of the Slovak Republic, Bratislava.

Lavecchia, L. and C. Stagnaro (2010), “Are Green Jobs Real Jobs? The Case of Italy”, Instituto Bruno Leoni, Torino.

Lawson, J. (2010), “European energy policy and the transition to a low-carbon economy”, Economics Department Working Papers, No. ${ }^{\circ 779}$, OECD, Paris.

Moncada-Paterno-Castello, P. et al. (2010), "Does Europe perform too little corporate R\&D? A comparison of EU and non-EU corporate R\&D performance”, Research Policy, 39(4), pp. 523-536.

Nickell, S. et al. (1997), “What Makes Firms Perform Well?”, European Economic Review, No. 41, pp. 783-796, NRP (implementation, 2008-10).

Nicoletti, G. and S. Scarpetta (2005), "Regulation and Economic Performance: Product Market Reforms and Productivity in the OECD”, Economics Department Working Papers, No. 460, OECD, Paris.

OECD (2003), Tax Incentives for Research and Development: Trends and Issues, OECD, Paris.

OECD (2004), The Economic Impact of ICT: Measurement, Evidence and Implications, OECD, Paris.

OECD (2005), OECD Economic Surveys: Slovak Republic, OECD, Paris.

OECD (2006), Boosting jobs and incomes - Policy Lessons from Reassessing the OECD Job Strategy, OECD, Paris.

OECD (2007), OECD Economic Surveys: Slovak Republic, OECD, Paris.

OECD (2009a), “Linkages between environmental policy and competitiveness”, Environment Working Papers, No. 13, OECD, Paris.

OECD (2009b), Science, Technology and Industry Scoreboard, OECD, Paris.

OECD (2009c), OECD Economic Surveys: Slovak Republic, OECD, Paris.

OECD (2009d), Towards Green ICT Strategies: Assessing Policies and Programmes on ICT and the Environment, OECD, Paris.

OECD (2010a), Taxation, Innovation and Environment, OECD, Paris.

OECD (2010b), Measuring Innovation: A new Perspective, OECD, Paris.

OECD (2010c), Eco-Innovation in Industry: Enabling Green Growth, OECD, Paris.

OECD (2010d), OECD Information Technology Outlook 2010, OECD, Paris. 
ECO/WKP(2011)74

OECD (2010f), Economic Survey: Slovak Republic, OECD, Paris.

OECD (2010e), OECD Employment Outlook 2010, Chapter 3: Institutional and Policy Determinants of Labour Market Flows, OECD, Paris.

Park, W. and D. Lippoldt (2008), “Technology Transfer and the Economic Implications of the Strengthening of Intellectual Property Rights in Developing Countries”, Trade Policy Working Papers, No. 62, OECD, Paris.

de Serres, A., F. Murtin and G. Nicoletti (2010), “A Framework for Assessing Green Growth Policies”, Economics Department Working Papers, No. 774, OECD, Paris.

Slovak Hydrometeorological Institute and Ministry of the Environment of the Slovak Republic (2009), Fifth national communication of the Slovak Republic on climate change, Brastislava.

Sorrel, S. (2007), The Rebound Effect: an assessment of the evidence for economy wide energy savings from improved energy efficiency, UK Energy Research Centre, UK.

World Bank (2010), Doing Business 2010: Reforming through Difficult Times, World Bank/International Finance Corporation, Washington, DC. 
ECO/WKP(2011)74

\section{Annex 1. Energy efficiency gains and rebound effects}

A cost efficient development of energy efficiency could lead to an increase in consumption of energy and energy-intensive goods. This "rebound effect" occurs through different channels:

Energy efficiency decreases the relative price of energy, which stimulates energy consumption (substitution effect, the direct rebound effect).

- Energy savings increase the purchasing power of consumers, inducing a rise in energy consumption (revenue effect).

- Energy savings reduce production costs and improve price-competitiveness. The production of efficient technologies, products and services develops new green sectors and activities. Savings on energy spending increase liquidity and funds for investments in the importing countries. These different mechanisms foster potential economic growth, which creates new energy needs (multiplier effects).

- A decrease in energy demand may lower energy prices, make energy more affordable and reduce the prices of energy-intensive goods and services.

The rebound effects are difficult to measure. The direct rebound effect depends on the elasticity of the energy demand to prices which is related to the degree of demand saturation in energy services, the income level and on the importance of energy prices in economic decisions. In consequence, the effect varies between technologies, sectors, income groups and could account for between zero and $50 \%$. On average, the literature finds a small to moderate direct rebound effect in developed countries (Geller, 2005). The indirect rebound effect is even more difficult to measure and no consensus emerges in the literature on its magnitude. The indirect rebound effects are more likely to appear when technologies used for general purposes are exploited (steam engines in the $19^{\text {th }}$ century, electric motors in the $20^{\text {th }}$ century) (Sorrel, 2007). The fourth effect (lowering of prices through decrease in demand) depends on the size of the country and is likely to be low in Slovakia.

As a whole, economic studies do not suggest that energy efficiency gains result in an increase in energy consumption. However they generally find a significant economy-wide impact: the rebound effects lower the expected energy savings by $10 \%$ at least and are particularly high in some sectors. Energy efficient technologies in energy-intensive sectors could lead to rebound effects exceeding $50 \%$ (Sorrel, 2007). These effects should be considered when defining an energy policy strategy and assessing its cost-effectiveness. High rebound effects must be also avoided by limiting the decline in the relative energy cost when efficiency improves. Other kinds of policies aiming at changing consumer preferences and increasing the energy prices are necessary to limit the rebound effect and limit waste in resources. 
ECO/WKP(2011)74

\section{WORKING PAPERS}

The full series of Economics Department Working Papers can be consulted at www.oecd.org/eco/workingpapers/

904. Fiscal reform for a stronger fairer and cleaner Mexican economy

(October 2011) by Nicola Brandt and Rodrigo Paillacar

903. The demand for safe assets in emerging economies and global unbalances: new empirical evidence (October 2011) by Rudiger Ahrend and Cyrille Schwellnus

902. Drivers of systemic banking crises: the role of bank-balance-sheet contagion and financial account structure

(October 2011) by Rudiger Ahrend and Antoine Goujard

901. Explaining the appreciation of the Brazilian Real

(October 2011) by Annabelle Mourougane

900. Raising investment in Brazil

(October 2011) by Jens Arnold

899. Refining macroeconomic policies to sustain growth in Brazil

(October 2011) by Annabelle Mourougane

898. Promoting infrastructure development in Brazil

(October 2011) by Annabelle Mourougane and Mauro Pisu

897. Austria: public sector inefficiencies have become less affordable

(October 2011) by Karin Fischer, Rauf Gönenç and Robert Price

896. Informality in Mexico

(September 2011) by Nicola Brandt

895. Reforming Austria's highly regarded but costly health system

(September 2011) by Rauf Gönenç, Maria. M. Hofmarcher, Andreas Wörgötter

894 Greener growth in the Belgian federation

(September 2011) by Tomasz Koźluk

893. Green growth and climate change policies in New Zealand (September 2011) by Alexandra Bibbee

892. Has deregulation increased investment in infrastructure? Firm-level evidence from OECD countries

(September 2011) by Sónia Araújo

891. Ensuring a Sustainable and Efficient Fishery in Iceland

(September 2011) by Gunnar Haraldsson and David Carey

890. Japan's New Growth Strategy to create demand and Jobs (September 2011) by Randall S. Jones and Byungseo Yoo 
889. Labour market reforms in Japan to improve growth and equity

(September 2011) by Randall S. Jones and Satoshi Urasawa

888. Education reform in Japan

(September 2011) by Randall S. Jones

887. The Political Economy of Climate Change Mitigation Policies: How to Build a Constituency to Address Global Warming?

(August 2011) by Alain de Serres, John Llewellyn and Preston Llewellyn

886. Climate-Change Policy in the United Kingdom

(August 2011) by Alex Bowen and James Rydge

885. Improving Access and Quality in the Indian Education System

(August 2011) by Sam Hill and Thomas Chalaux

884. How Institutions Shape the Distributive Impact of Macroeconomic Shocks: A DSGE Analysis

(July 2011) by Rudiger Ahrend, Charlotte Moeser and Tommaso Monacelli

883. Can India Achieve Double-Digit Growth?

(July 2011) by Richard Herd, Paul Conway, Sam Hill, Vincent Koen and Thomas Chalaux

882. Predicting peaks and troughs in real house prices

(July 2011) by Linda Rousová and Paul van den Noord

881. Public sector spending efficiency in Estonia: healthcare and local government

(July 2011) by Zuzana Smidova

880. How to move Product Market Regulation in New Zealand back towards the frontier (July 2011) by Paul Conway

879. Financial sector reform in India: time for a second wave?

(July 2011) by Richard Herd, Vincent Koen, Ila Paitnak and Ajay Shah

878. Policies to rebalance housing markets in New Zealand

(July 2011) by Calista Cheung

877. The sharing of macroeconomic risk: Who loses (and gains) from macroeconomic shocks (July 2011) Rudiger Ahrend, Jens Arnold and Charlotte Moeser

876. Estonia: making the most of globalisation

(June 2011) Robert Price and Andreas Wörgötter

875. The effects of downturns on labour force participation: evidence and causes (June 2011) Romain Duval, Mehmet Eris and Davide Furceri

874 A dynamic factor model for world trade growth

(June 2011) Stéphanie Guichard and Elena Rusticelli

873. Towards a better understanding of the informal economy

(May 2011) Dan Andrews, Aida Caldera Sánchez and Åsa Johansson 